University of Montana

ScholarWorks at University of Montana

Numerical Terradynamic Simulation Group

Publications

Numerical Terradynamic Simulation Group

$11-2010$

\title{
Analysis of the Arctic System for Freshwater Cycle Intensification: Observations and Expectations
}

\author{
Michael A. Rawlins \\ Michael Steele \\ Marika M. Holland \\ Jennifer C. Adam \\ Jessica E. Cherry \\ See next page for additional authors
}

Follow this and additional works at: https://scholarworks.umt.edu/ntsg_pubs

Let us know how access to this document benefits you.

\section{Recommended Citation}

Rawlins, M., M. Steele, M. Holland, J. Adam, J. Cherry, J. Francis, P. Groisman, L. Hinzman, T. Huntington, D. Kane, J. Kimball, R. Kwok, R. Lammers, C. Lee, D. Lettenmaier, K. McDonald, E. Podest, J. Pundsack, B. Rudels, M. Serreze, A. Shiklomanov, Ø. Skagseth, T. Troy, C. Vörösmarty, M. Wensnahan, E. Wood, R. Woodgate, D. Yang, K. Zhang, and T. Zhang, 2010: Analysis of the Arctic System for Freshwater Cycle Intensification: Observations and Expectations. J. Climate, 23, 5715-5737, doi: 10.1175/2010JCLI3421.1

This Article is brought to you for free and open access by the Numerical Terradynamic Simulation Group at ScholarWorks at University of Montana. It has been accepted for inclusion in Numerical Terradynamic Simulation Group Publications by an authorized administrator of ScholarWorks at University of Montana. For more information, please contact scholarworks@mso.umt.edu. 


\section{Authors}

Michael A. Rawlins, Michael Steele, Marika M. Holland, Jennifer C. Adam, Jessica E. Cherry, Jennifer A. Francis, Pavel Ya. Groisman, Larry D. Hinzman, Thomas G. Huntington, Douglas L. Kane, John S. Kimball, Ron Kwok, Richard Lammers, Craig M. Lee, Dennis P. Lettenmaier, Kyle C. McDonald, Erika Podest, Jonathan Pundsack, Bert Rudels, Mark C. Serreze, Alexander Shiklomanov, Oystein Skagseth, Tara J. Troy, C. J. Vorosmarty, Mark Wensnahan, Eric F. Wood, Rebecca Woodgate, Daqing Yang, Ke Zhang, and Tingjun Zhang 


\section{Analysis of the Arctic System for Freshwater Cycle Intensification: Observations and Expectations}

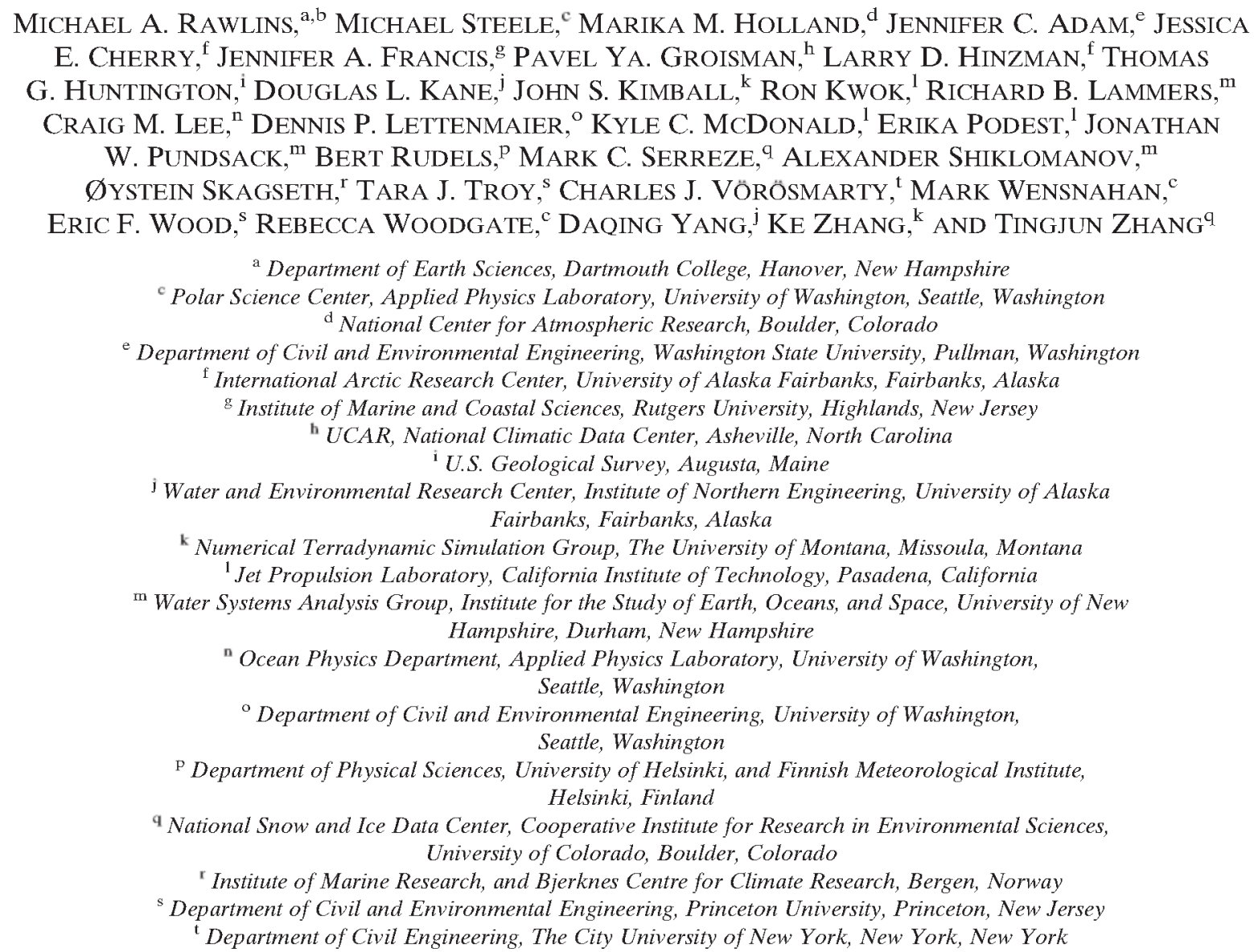

(Manuscript received 9 September 2009, in final form 1 June 2010)

ABSTRACT

Hydrologic cycle intensification is an expected manifestation of a warming climate. Although positive trends in several global average quantities have been reported, no previous studies have documented broad intensification across elements of the Arctic freshwater cycle (FWC). In this study, the authors examine the character and quantitative significance of changes in annual precipitation, evapotranspiration, and river discharge across the terrestrial pan-Arctic over the past several decades from observations and a suite of

${ }^{\mathrm{b}}$ Current affiliation: Department of Geosciences, University of Massachusetts, Amherst, Massachusetts.

Corresponding author address: Michael A. Rawlins, Dept. of Geosciences, University of Massachusetts, Amherst, MA 01003 E-mail: rawlins@geo.umass.edu

DOI: $10.1175 / 2010 J C L I 3421.1$

(C) 2010 American Meteorological Society 
coupled general circulation models (GCMs). Trends in freshwater flux and storage derived from observations across the Arctic Ocean and surrounding seas are also described.

With few exceptions, precipitation, evapotranspiration, and river discharge fluxes from observations and the GCMs exhibit positive trends. Significant positive trends above the $90 \%$ confidence level, however, are not present for all of the observations. Greater confidence in the GCM trends arises through lower interannual variability relative to trend magnitude. Put another way, intrinsic variability in the observations tends to limit confidence in trend robustness. Ocean fluxes are less certain, primarily because of the lack of long-term observations. Where available, salinity and volume flux data suggest some decrease in saltwater inflow to the Barents Sea (i.e., a decrease in freshwater outflow) in recent decades. A decline in freshwater storage across the central Arctic Ocean and suggestions that large-scale circulation plays a dominant role in freshwater trends raise questions as to whether Arctic Ocean freshwater flows are intensifying. Although oceanic fluxes of freshwater are highly variable and consistent trends are difficult to verify, the other components of the Arctic FWC do show consistent positive trends over recent decades. The broad-scale increases provide evidence that the Arctic FWC is experiencing intensification. Efforts that aim to develop an adequate observation system are needed to reduce uncertainties and to detect and document ongoing changes in all system components for further evidence of Arctic FWC intensification.

\section{Introduction}

Climatic warming has been greatest across northern high latitudes in recent decades, and precipitation $(P)$ increases have been noted over some Arctic regions (Berner et al. 2005). In its Fourth Assessment Report (AR4), the Intergovernmental Panel on Climate Change (IPCC) stated that "increases in the amount of precipitation are very likely in high latitudes" (Solomon et al. 2007). This statement arises from model studies that suggest climate warming will result in hydrologic cycle "intensification." But what is meant by the term intensification and why do we expect these changes as a result of warming?

Intensification is considered here to be an increase in the freshwater (FW) fluxes between the Arctic's atmospheric, land, and ocean domains. Conceptually, intensification can be illustrated by an arrow connecting two boxes in a schematic diagram, where the boxes represent stocks of water in these domains (e.g., see Fig. 4 in Serreze et al. 2006). For any given flux (arrow) between stocks (boxes), a more intense flux would be represented by a larger arrow. More water is now moving between or within the respective domains. For example, river discharge (volume/time $=$ flux) in 1999 was approximately $128 \mathrm{~km}^{3} \mathrm{yr}^{-1}$ greater than it was when measurements began in the early 1930s (Peterson et al. 2002), a trend of $2.0 \mathrm{~km}^{3} \mathrm{yr}^{-2}$. In our schematic diagram, the arrow connecting the land to the ocean has increased in size.

Why should water cycle intensification be expected? Intensification is a critical aspect of the planetary response to warming, related to the atmosphere's ability to hold more water as it warms as defined by the theoretical Clausius-Clapeyron relation. Allen and Ingram (2002) noted that the Clausius-Clapeyron relation predicts that tropospheric moisture loading would result in precipitation increasing by about $6.5 \% \mathrm{~K}^{-1}$ of warming. Climate models, however, predict a substantially weaker sensitivity to warming on the order of $1 \%-3.4 \% \mathrm{~K}^{-1}$ because of constraints in the exchange of mass between the boundary layer and the midtroposphere (Held and Soden 2006; Lambert and Webb 2008). Recent analyses have indicated that surface specific humidity (Willett et al. 2008) and total atmospheric water content, precipitation, and evaporation (Wentz et al. 2007) appear to be increasing at rates more consistent with the ClausiusClapeyron equation than those predicted by general circulation models (GCMs). This question, related to sensitivity of the hydrologic system to warming, is of key importance for understanding future climatic responses, as water vapor is itself a greenhouse gas that acts as a feedback to amplify temperature change forced by anthropogenic increases in $\mathrm{CO}_{2}$ and $\mathrm{CH}_{4}$. Intensification is also likely to result in alterations of the hydrologic cycle in terms of the geographic distribution, amount, and intensity of precipitation that may lead to more flooding and drought. Finally, increases in atmospheric water vapor content will likely exacerbate heat stress (Gaffen and Ross 1998) and increase stomatal conductance (Wang et al. 2009).

Simulations with GCMs suggest future increases in pan-Arctic precipitation and evapotranspiration (ET; Holland et al. 2006; Kattsov et al. 2007), with the precipitation increases expected to outpace increases in evapotranspiration, resulting in an upward trend in net precipitation $(P-\mathrm{ET})$ over time. Indeed, an analysis of simulated changes from 10 models included in IPCC AR4 for the years 1950-2050 found a consistent acceleration of the Arctic hydrologic cycle as expressed by an increase in the fluxes of net precipitation, river runoff, and net ice melt passing through the Arctic's atmospheric, land, and ocean domains (Holland et al. 2007). Other model experiments suggest increased probabilities 
this century for quantities such as winter precipitation, including its intensity and the number of "heavy" precipitation events across northern Eurasia (Khon et al. 2007).

Studies describing global trends suggest that intensification may be occurring. A recent review by Huntington (2006) lists precipitation, evapotranspiration, and river discharge among the quantities that are increasing. Recent studies focusing on major river basins have shown that evapotranspiration is increasing (Berbery and Barros 2002; Serreze et al. 2002; Walter et al. 2004; Park et al. 2008). Fernandes et al. (2007) have reported trends toward increasing ET over Canada for the period 1960 2000 based on in situ climate observations and a land surface model (LSM). Satellite observations over the last three decades have shown increases in precipitation, $\mathrm{ET}$, and atmospheric water vapor content on a global scale (Wentz et al. 2007). Weak positive global trends have been reported in recent decades for soil moisture (Sheffield and Wood 2007) and precipitation recycling (Dirmeyer and Brubaker 2007). However, Serreze et al. (2002) found no trends in precipitation recycling ratio for the Lena, Yenisey, $\mathrm{Ob}$, or Mackenzie basins from 1960 to 1999 . There is also growing evidence for an increase in indices of precipitation extremes (Alexander et al. 2006; Tebaldi et al. 2006). The eruption of Mount Pinatubo and subsequent massive introduction of $\mathrm{SO}_{2}$ into the stratosphere in 1991 provided a natural experiment in planetary cooling that resulted in a weakening (dampening) of the global hydrologic cycle that is the reverse analog to climate warming. In the $2 \mathrm{yr}$ following the eruption, there was a decrease in atmospheric water content (Santer et al. 2007) and a decrease in precipitation and continental discharge (Trenberth and Dai 2007). Across some regions of the Arctic, precipitation increases have been as much as $15 \%$ over the last $100 \mathrm{yr}$ (Berner et al. 2005), with most of the trend having occurred during winter within the last $40 \mathrm{yr}$ (Bradley et al. 1987; Groisman et al. 1991; Hanssen-Bauer and Forland 1994). Long-term increases in pan-Arctic precipitation, however, have not been established.

Substantial progress in our understanding and quantification of the Arctic freshwater cycle (FWC) has been made over the past decade. In 2000, a comprehensive, integrated view of the Arctic Ocean freshwater budget and potential future changes were presented in "The Freshwater Budget of the Arctic Ocean" (Lewis 2000). Other studies have described changes in the Arctic FWC (Peterson et al. 2002, 2006), quantified the mean freshwater budget (Serreze et al. 2006), and examined freshwater components depicted within coupled models (Kattsov et al. 2007; Holland et al. 2007). Linkages between freshening of polar oceans and an intensifying Arctic FWC have also been posited (Dickson et al. 2002;
Curry et al. 2003; Peterson et al. 2006). In a study examining 925 of the world's largest ocean-reaching rivers, Dai et al. (2009) showed that rivers having statistically significant downward trends (45) outnumber those with upward trends (19). However, for large Arctic rivers, they report a large upward trend in annual discharge into the Arctic Ocean from 1948 to 2004. Nonetheless, Polyakov et al. (2008) and others have found that the historical data indicate a decrease in Arctic Ocean freshwater storage. While the slow but steady increase in river discharge might be expected to eventually increase ocean freshwater storage and export to the south, the magnitude and time scale of this forcing can be easily overwhelmed by advective exchanges between ocean regions.

This paper presents a systematic analysis of change in the Arctic FWC through a comparison of trends drawn from observations and a suite of GCM simulations. We focus on the sign and magnitude of change in fluxes such as precipitation, river discharge, and liquid freshwater transport in the Arctic Ocean. Section 2 is an overview of the GCMs used in our analysis. Section 3 describes the terrestrial observations, reanalysis data, and associated trends. Section 4 is a synthesis of Arctic Ocean FWC components. Results are summarized in Section 5. This study builds on previous studies supported under the National Science Foundation Arctic System Science Freshwater Integration study (FWI), which have quantified the large-scale freshwater budget (Serreze et al. 2006), characterized freshwater anomalies within the Mackenzie River basin and the Beaufort Gyre (Rawlins et al. 2009a), documented changes and feedbacks in the freshwater system (White et al. 2007; Francis et al. 2009), and described projected freshwater changes over the twenty-first century (Holland et al. 2007).

\section{General circulation models}

Variability and trends in the Arctic FWC are drawn from nine models examined in the World Climate Research Programme's (WCRP's) Coupled Model Intercomparison Project phase 3 (CMIP3) multimodel dataset (Table 1). These models were also part of IPCC AR4 (Solomon et al. 2007). Details of the model characteristics and forcings are described in Holland et al. (2007), who selected this model subset given their ability to resolve the passage of water through the Bering and Fram Straits. Outputs examined here are from each model control run of twentieth-century climate followed by future simulations using the Special Report on Emissions Scenarios (SRES) A1B scenario. In addition to these nine models, Holland et al. also examined output from the Goddard Institute for Space Studies Model E-R (GISS E-R), which we do not use given known problems 
TABLE 1. GCMs used in the analysis. Models listed in Table 4 are referenced by the model number shown here.

\begin{tabular}{|c|c|c|c|c|c|c|}
\hline No. & Model & $P, \mathrm{ET}$ & $\begin{array}{l}\text { Ice transport } \\
\text { Fram Strait }\end{array}$ & $\begin{array}{l}\text { Ocean transport } \\
\text { Bering Strait }\end{array}$ & $\begin{array}{c}\text { Ice } \\
\text { storage }\end{array}$ & $\begin{array}{l}\text { Ocean } \\
\text { storage }\end{array}$ \\
\hline 1 & CGCM3.1 (T63) & $\mathrm{X}$ & $\mathrm{X}$ & $\mathrm{X}$ & $\mathrm{X}$ & $\mathrm{X}$ \\
\hline 2 & $\begin{array}{l}\text { Centre National de Recherches Météorologiques } \\
\text { Coupled Global Climate Model, version } 3 \text { (CNRM-CM3) }\end{array}$ & $\mathrm{X}$ & $\mathrm{X}$ & $\mathrm{X}$ & $\mathrm{X}$ & $\mathrm{X}$ \\
\hline 3 & $\begin{array}{l}\text { Commonwealth Scientific and Industrial Research } \\
\text { Organisation Mark version 3.0 (CSIRO Mk3.0) }\end{array}$ & $\mathrm{X}$ & $\mathrm{X}$ & $\mathrm{X}$ & $\mathrm{X}$ & $\mathrm{X}$ \\
\hline 4 & GISS Atmosphere-Ocean Model (GISS-AOM) & $\mathrm{X}$ & $\mathrm{X}$ & $\mathrm{X}$ & $\mathrm{X}$ & $\mathrm{X}$ \\
\hline 5 & MIROC3.2[medium resolution (medres)] & $\mathrm{X}$ & $\mathrm{X}$ & $\mathrm{X}$ & $\mathrm{X}$ & $\mathrm{X}$ \\
\hline 6 & $\operatorname{CCSM} 3$ & $\mathrm{X}$ & $\mathrm{X}$ & $\mathrm{X}$ & $\mathrm{X}$ & $\mathrm{X}$ \\
\hline 7 & $\begin{array}{l}\text { Third climate configuration of the Met Office Unified } \\
\text { Model (UKMO HadCM3) }\end{array}$ & $\mathrm{X}$ & $\mathrm{X}$ & $\mathrm{X}$ & $\mathrm{X}$ & $\mathrm{X}$ \\
\hline 8 & $\begin{array}{l}\text { Met Office Hadley Centre Global Environmental Model } \\
\text { version } 1 \text { (UKMO HadGEM1) }\end{array}$ & $\mathrm{X}$ & $\mathrm{X}$ & & $\mathrm{X}$ & \\
\hline 9 & GFDL-CM2.1 & $\mathrm{X}$ & $\mathrm{X}$ & & $\mathrm{X}$ & \\
\hline
\end{tabular}

in its depictions of observed climate over the region of interest (Gorodetskaya et al. 2008; Holland et al. 2010). In the analysis to follow, a time series for each model represents a single model simulation, as not all models had multiple ensemble members. Holland et al. (2007) examined results across a terrestrial Arctic drainage region, which included the large Eurasian river basins ( $\mathrm{Ob}$, Yenesei, and Lena), the Mackenzie basin in North America, and northern parts of Alaska, Greenland, and the Canadian Archipelago (light gray in Fig. 1). In the present study, pan-Arctic averages for the observations are determined over the larger region shown in Fig. 1 (light gray plus dark gray). We minimize the effect of differing volumes by computing and presenting unit depths for all budget and trend magnitudes. Holland et al. (2007) contains additional details of the GCMs and associated simulations.

One of the more interesting findings from Holland et al. (2007) is an intensification of fluxes such as net precipitation, river runoff, and export of liquid freshwater to lower latitudes. Holland et al. (2007) suggested that net precipitation over the Arctic terrestrial drainage increases from 1950 through 2050 by $16 \%$, with most of this change occurring after 2000 . Although intensification among the models is universal, the magnitude of change ranges widely. Moreover, the change in terrestrial net precipitation among the models is significantly correlated with initial values. In other words, models with higher initial net precipitation amounts generally exhibit larger changes.

\section{Terrestrial system}

\section{a. Precipitation}

Several sources of data, averaged over the terrestrial Arctic drainage basin (light gray plus dark gray in Fig. 1) excluding Greenland, are used to characterize precipitation trends and variability. This region and the smaller Arctic domain used by Holland et al. (2007) and Serreze et al. (2006) are shown in Fig. 1. Records derived largely from interpolations of gauge observations come from three sources; the Willmott-Matsuura (WM) archive (Willmott and Matsuura 2009), the Climate Research Unit (CRU) version 3.0 dataset (Climatic Research Unit 2009), and the data presented by Sheffield et al. (2006, hereafter referred to as $\mathrm{S} 06$ ). The latter data $(\mathrm{S} 06)$ is a $1^{\circ}$, 3-hourly global meteorological forcings dataset from 1948 through 2000 . The precipitation data were created

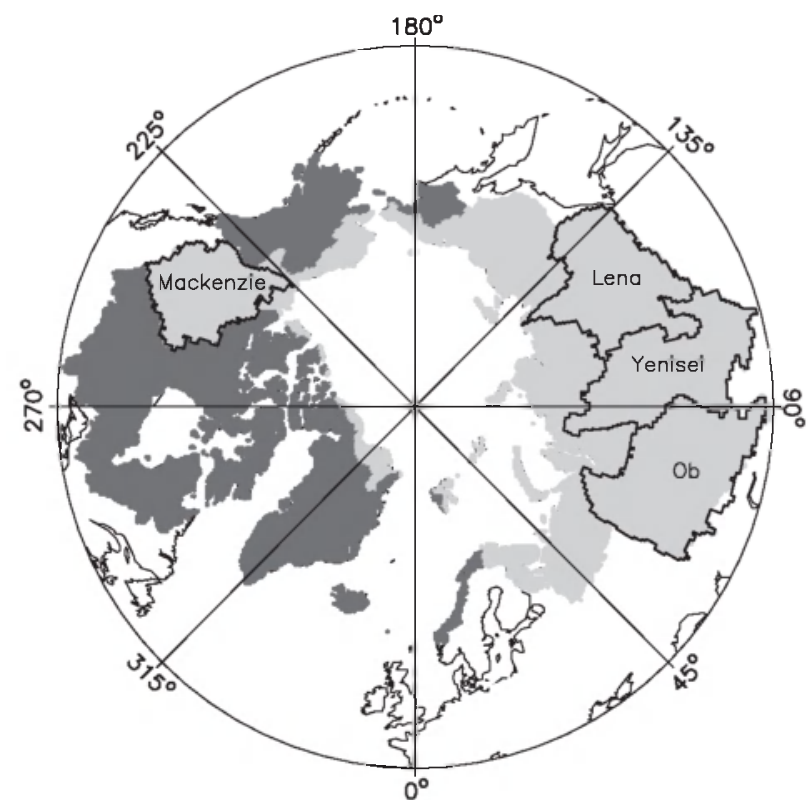

FIG. 1. Arctic drainage as defined for the GCM analysis (light gray) and the full pan-Arctic basin over which the observed data were averaged (includes light + dark gray regions). The four largest Arctic basins are also outlined. 
by sampling the National Centers for Environmental Prediction-National Center for Atmospheric Research (NCEP-NCAR) reanalysis data for daily variability after correcting for rain-day anomalies across the high latitudes. Monthly precipitation was scaled to match the CRU version 2.0 dataset (Mitchell et al. 2004). Given the monthly scaling, trends in S06 precipitation should be equivalent to trends in CRU data. We use an updated version of S06 that does not include undercatch corrections but does incorporate improvements to relative humidity estimates across the Arctic. Gridded precipitation data are also drawn from the Global Precipitation Climatology Project (GPCP). Established by the World Climate Research Programme, the GPCP draws on data from over 6000 rain gauge stations as well as satellite geostationary and low-orbit infrared, passive microwave, and sounding observations. Several GPCP products are available. We examine here the monthly data on a $1^{\circ}$ global grid. We also analyze precipitation from the Global Precipitation Climatology Center's (GPCC's) dataset that is based on a quality-controlled data product optimized for the best spatial coverage and use in water budget studies.

Precipitation and ET are also available from reanalysis, a retrospective form of numerical weather prediction (NWP). Reanalysis involves assimilation of observations within a coupled atmospheric-land surface model and produces time series of gridded atmospheric fields and surface state variables in a consistent manner. The 40-yr European Centre for Medium-Range Weather Forecasts (ECMWF) Re-Analysis (ERA-40) archives precipitation and ET along with other atmospheric fields and surface state variables for the period 1948-2002 (Kalnay et al. 1996), although data since 1979 (the advent of modern satellite data streams) are generally of higher quality (Bromwich and Fogt 2004). More recently the ERAInterim project has created gridded fields for 1989-2005 with improvements from the ERA-40, including a fourdimensional (4D) variational assimilation system and improved global hydrologic cycle. Data from the ERA-40 reanalysis were recently used in a comprehensive analysis of the Arctic's freshwater budget and variability (Serreze et al. 2006). Mean terrestrial budget magnitudes from that analysis are compared with those from our precipitation, ET, and river discharge data and from which trends are derived.

Gridded fields in both WM and CRU archives were produced through interpolations of precipitation observations, with the point data having originated from gauge measurements. Relative to precipitation across temperate regions, observations of precipitation over the terrestrial Arctic are more sparse and, moreover, subject to considerable uncertainties. Two significant sources of error make climate change analysis of precipitation particularly challenging. First, observations recorded at gauges are subject to several errors, with undercatch, particularly in the solid form, generally the greatest (Groisman et al. 1991). Low biases are often as high as $80 \%-120 \%$ in winter across coastal regions with strong winds (Bogdanova et al. 2002; Yang et al. 2005; Goodison et al. 1998). These biases can also change over time. Raw gauge observations used to create the WM and CRU datasets are devoid of undercatch adjustments. Second, direct observations across the Arctic are extremely sparse and station closures have occurred since the early 1990s (Schiermeier 2006). A changing configuration of stations can also impart biases into temporal trends derived from the historical station network (Keim et al. 2005; Rawlins et al. 2006). Biases due to a changing station network are minimized by focusing on time periods starting in 1950 when the station network was less variable.

Trend analysis of pan-Arctic (excluding Greenland) annual precipitation and other water budget terms is accomplished using linear least squares regression and a two-tailed significance test. The precipitation and other annual time series examined contain minimal temporal autocorrelation and no adjustments to the raw data are made. Precipitation-trend-slope magnitudes range from -0.03 to $0.79 \mathrm{~mm} \mathrm{yr}^{-2}$, with two of the six observed series showing upward trends above the $90 \%$ confidence level (Table 2). A significant positive trend of $0.21 \mathrm{~mm} \mathrm{yr}^{-2}$ is noted with the CRU version 3.0 dataset (Fig. 2, Table 2). Time series from both S06 and WM effectively show no trend. Relatively low precipitation magnitudes with these data (Table 3) are likely attributable to a lack of adjustments for gauge undercatch. Both GPCP and GPCC data show positive tendencies ( 0.74 and $0.43 \mathrm{~mm} \mathrm{yr}^{-2}$, respectively) over recent decades, but they are both too short to yield significant trends. ERA-Interim exhibits the largest $\left(0.79 \mathrm{~mm} \mathrm{yr}^{-2}\right.$, significant) trend. It is interesting to note that precipitation data available over the latter decades of the twentieth century (GPCP, GPCC, and ERA-Interim) show sharper increases than the longer records. All of the precipitation datasets have mean annual totals within $15 \%$ of the best estimates described in Serreze et al. (2006) from 1979 to 1993 (Table 3).

Figure 3a shows the precipitation time series (19501999) from the nine GCMs, the linear trend fits, and the multimodel mean trend. Trends are all positive, ranging from 0.12 to $0.63 \mathrm{~mm} \mathrm{yr}^{-2}$, with a multimodel mean trend of $0.37 \mathrm{~mm} \mathrm{yr}^{-2}$ (Fig. 4a; Table 4). Significant increases are noted for all but the Community Climate System Model, version 3 (CCSM3) and the Geophysical Fluid Dynamics Laboratory Climate Model version 2.1 
TABLE 2. Trends and CVs for terms of the terrestrial water budget. Null hypothesis is no trend over the specified time period. Slope and statistical significance are determined using linear least squares regression and the Student's $t$ test. Terms significant at $p<0.1$ ( $90 \%$ confidence) are indicated in bold. Entries in each section are ordered by length of record. Trends and CVs for individual GCMs are shown in Fig. 4.

\begin{tabular}{|c|c|c|c|}
\hline Term & $\begin{array}{l}\text { Time } \\
\text { period }\end{array}$ & $\begin{array}{c}\text { Trend } \\
\left(\mathrm{mm} \mathrm{yr}^{-2}\right)\end{array}$ & $\mathrm{CV}(\%)$ \\
\hline \multicolumn{4}{|l|}{ Precipitation } \\
\hline CRU version 3.0 & $1950-2006$ & 0.21 & 2.8 \\
\hline WM & 1950-2006 & -0.03 & 2.7 \\
\hline GCMs & 1950-1999 & 0.37 & - \\
\hline S06 & 1950-1999 & 0.11 & 2.5 \\
\hline GPCP & $1983-2005$ & 0.74 & 3.2 \\
\hline GPCC & $1983-2005$ & 0.43 & 2.6 \\
\hline ERA-Interim & $1989-2005$ & 0.79 & 1.7 \\
\hline \multicolumn{4}{|l|}{ Evapotranspiration } \\
\hline $\mathrm{GCMs}$ & 1950-1999 & 0.17 & - \\
\hline VIC & 1950-1999 & 0.11 & 3.6 \\
\hline $\mathrm{LSMs}^{\mathrm{a}}$ & 1980-1999 & 0.40 & 2.2 \\
\hline $\mathrm{RS}^{\mathrm{b}}$ & $1983-2005$ & 0.38 & 2.6 \\
\hline ERA-Interim & 1989-2005 & 0.30 & 2.5 \\
\hline \multicolumn{4}{|l|}{ River Discharge } \\
\hline North America ${ }^{\mathrm{C}}$ & $1950-2005$ & 0.40 & 9.5 \\
\hline North America ${ }^{\mathrm{d}}$ & $1950-2005$ & 0.12 & 7.4 \\
\hline Hudson Bay & $1950-2005$ & -0.29 & 9.4 \\
\hline Pan-Arctic & $1950-2004$ & 0.23 & 4.5 \\
\hline Eurasia $^{\mathrm{e}}$ & $1950-2004$ & 0.31 & 4.8 \\
\hline $\mathrm{GCMs}, P-\mathrm{ET}$ & 1950-1999 & 0.20 & - \\
\hline JRA-25, $P-\mathrm{ET}$ & $1979-2007$ & 0.35 & 4.5 \\
\hline$P-\mathrm{ET}^{\mathrm{f}}$ & $1983-2005$ & 0.36 & 5.6 \\
\hline$P-\mathrm{ET}^{\mathrm{g}}$ & $1983-2005$ & 0.05 & 5.8 \\
\hline
\end{tabular}

${ }^{a}$ Model mean ET of LSMs from Slater et al. (2007).

${ }^{b}$ ET estimated from remote sensing with AVHRR GIMMS data.

${ }^{\mathrm{c}}$ Excluding the drainage to Hudson Bay.

${ }^{\mathrm{d}}$ Including the drainage to Hudson Bay.

'For the six largest Eurasian rivers.

${ }^{\mathrm{f}}$ ET estimated from GPCP $P$ minus RS ET.

${ }^{g}$ ET estimated from GPCC $P$ minus RS ET.

(GFDL CM2.1) models. Over the $100-y r$ period from 1950 to 2049 , trends range from 0.24 to as much as $0.92 \mathrm{~mm} \mathrm{yr}^{-2}$, with the multimodel mean trend at $0.65 \mathrm{~mm} \mathrm{yr}^{-2}$ (Fig. 4b). This suggests an acceleration over the latter $50 \mathrm{yr}$. Regarding significance, greater confidence can be ascribed to the GCM precipitation increases, compared to the observational data trends, largely because of a combination of higher trend magnitudes and longer time periods relative to the interannual variability as reflected by the respective coefficient of variation $(\mathrm{CV})$. This follows from principles of statistical significance tests, in that the required sample size to detect a particular change depends on the magnitude of the change, variability of the data, and the nature of the test. These influences are evident when comparing the GCM trend magnitudes and CVs in Fig. 4 with those for the

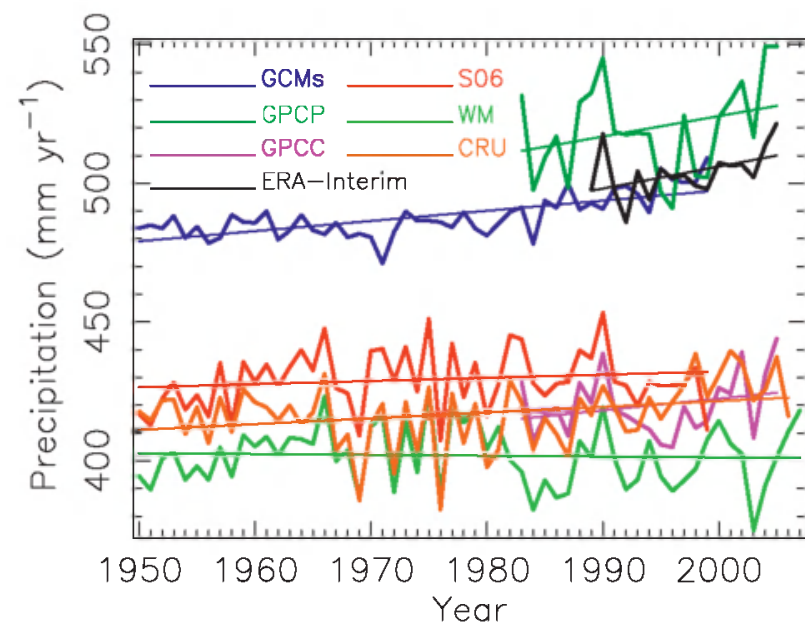

FIG. 2. Annual precipitation for the full pan-Arctic drainage basin (light + dark gray regions) shown in Fig. 1. Time series are from CRU, the ERA-Interim dataset, the multimodel mean from the nine GCMs, GPCP, GPCC, S06, and the WM dataset. See also Tables 2 and 3 and section 3 a. Linear least squares trend fit through annual values is shown.

observations in Table 2. Intermodel scatter in pan-Arctic precipitation is likely related to process error such as model parameterizations of relevant precipitation processes, which often explain the spatial consistency in this error term (Finnis et al. 2009).

An increase in extreme precipitation events is also expected as the climate warms (Held and Soden 2006). Precipitation data (Groisman et al. 2003, 2005; Tebaldi et al. 2006) show an increase in heavy precipitation events $(>2 \sigma$ of the events with precipitation $>0.5 \mathrm{~mm}$ ) over western Russia $\left(30^{\circ}-80^{\circ} \mathrm{E}\right)$ and northern Europe; opposite tendencies have been noted for the Asian part of northwestern Eurasia, with more droughts and stronger and/or more frequent weather conducive to fires (Groisman et al. 2007; Soja et al. 2007). A circumpolar increase of $12 \%$ has occurred for heavy precipitation events since 1950 for the region north of $50^{\circ} \mathrm{N}$, with most of the increase having come from Eurasia, where an increase in convective clouds during spring and summer has been observed (Groisman et al. 2007). Yet, while precipitation extremes are likely related to warming and associated increases in atmospheric water vapor, simple models suggest that they may not be expected to increase at the rate given by Clausius-Clapeyron scaling because of changes in the moist-adiabatic lapse rate, which lowers the rate of the precipitation increases due to warming (O'Gorman and Schneider 2009).

Spatial estimates of precipitation suffer from two significant sources of uncertainty: gauge undercatch and a sparse station network. How do the uncertainties related to network arrangement and gauge catch affect 
TABLE 3. Mean magnitude of terms of the pan-Arctic terrestrial water budget. Entries are ordered the same as in Table 2. Period over which the quantities in each category are derived is shown in each heading. The first row in each category lists the value of the best estimate from Serreze et al. (2006) derived from the ERA-40 reanalysis.

\begin{tabular}{|c|c|}
\hline Term & Magnitude $\left(\mathrm{mm} \mathrm{yr}^{-1}\right)$ \\
\hline \multicolumn{2}{|l|}{ Precipitation, 1979-93 } \\
\hline Serreze et al. & 490 \\
\hline CRU V3 & 410 \\
\hline Willmott-Matsuura & 420 \\
\hline GCMs & 490 \\
\hline S06 & 430 \\
\hline GPCP & 520 \\
\hline GPCC & 420 \\
\hline ERA-Interim & 510 \\
\hline \multicolumn{2}{|c|}{ Evapotranspiration, 1979-93 } \\
\hline Serreze et al. & 310 \\
\hline GCMs & 270 \\
\hline VIC & 150 \\
\hline $\operatorname{LSMs}^{\mathrm{a}}$ & 210 \\
\hline $\mathrm{RS}^{\mathrm{b}}$ & 230 \\
\hline ERA-Interim & 280 \\
\hline \multicolumn{2}{|c|}{ River discharge, 1979-2001 } \\
\hline Serreze et al. $P-\mathrm{ET}$ & 180 \\
\hline North America ${ }^{\mathrm{C}}$ & 220 \\
\hline North America ${ }^{\mathrm{d}}$ & 230 \\
\hline Hudson Bay & 250 \\
\hline Pan-Arctic & 230 \\
\hline Eurasia $^{\mathrm{e}}$ & 230 \\
\hline GCMs, $P-$ ET & 220 \\
\hline JRA-25, $P-\mathbf{E T}$ & 200 \\
\hline$P-\mathrm{ET}^{\mathrm{f}}$ & 290 \\
\hline$P-\mathrm{ET}^{\mathrm{g}}$ & 190 \\
\hline
\end{tabular}

${ }^{\mathrm{a}}$ Model mean ET of LSMs from Slater et al. (2007).

${ }^{\mathrm{b}}$ ET estimated from remote sensing with AVHRR-GIMMS data.

${ }^{\mathrm{c}}$ Excluding the drainage to Hudson Bay.

${ }^{\mathrm{d}}$ Including the drainage to Hudson Bay.

${ }^{\mathrm{e}}$ For the six largest Eurasian rivers.

${ }^{\mathrm{f}}$ ET estimated from GPCP $P$ minus RS ET.

${ }^{g}$ ET estimated from GPCC $P$ minus RS ET.

the annual precipitation trends? One study of bias adjustment has suggested that precipitation trends are higher after adjusting for gauge undercatch (Yang et al. 2005). However, Førland and Hanssen-Bauer (2000) argued that a warming climate is imparting a false positive trend into the data records because of a more efficient catch of liquid precipitation over time. An examination of both the raw and adjusted (for undercatch) records from the TD9813 archive of former USSR meteorological stations (National Climatic Data Center 2005), from 1950 through 1999, reveals that bias adjustments were greater during the earlier decades than the later ones. Thus, undercatch adjustment could tend to reduce the positive slopes presented in Fig. 2. The network bias, on the other hand, is likely to have the opposite effect on the annual precipitation trends. Station networks during
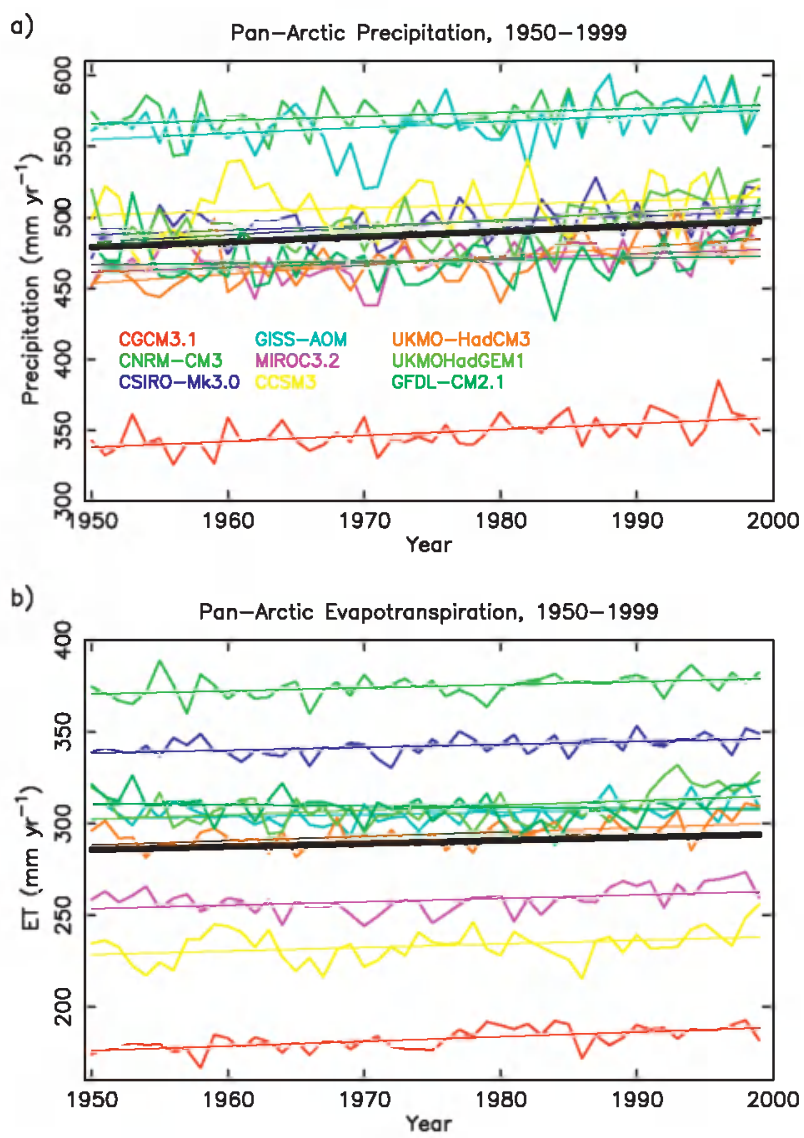

FIG. 3. (a) Precipitation and (b) evapotranspiration averaged over the terrestrial pan-Arctic 1950-99 from the nine GCMs (Table 1). Linear least squares trend fit is shown for each model. The heavy black line is the multimodel mean trend.

the early decades of the twentieth century were established across more southern parts of the terrestrial Arctic. In time, observations were established in the colder and drier north. Regionally averaged precipitation values from early arctic networks would thus tend to show positive bias relative to values from more recent arctic networks (Rawlins et al. 2006). Although the effect from 1950 through 1999 is likely small $\left(<10 \mathrm{~mm} \mathrm{yr}^{-1}\right)$, adjusting for the bias in network configuration would likely increase the trend slopes shown in Fig. 2, an effect opposite in sign to bias due to gauge undercatch. There is also a tendency for gauges to be located at lower elevations, causing an underestimation in precipitation in areas where there are mountains and strong orographic effects.

\section{b. Evapotranspiration}

Surface-based observations of ET across the pan-Arctic are sparse. Among the active sites in the Ameriflux program (available online at http://public.ornl.gov/ameriflux/ index.html), only three are located within the Arctic 
a) Trend in Annual Pan-Arctic Precipitation, 1950-1999

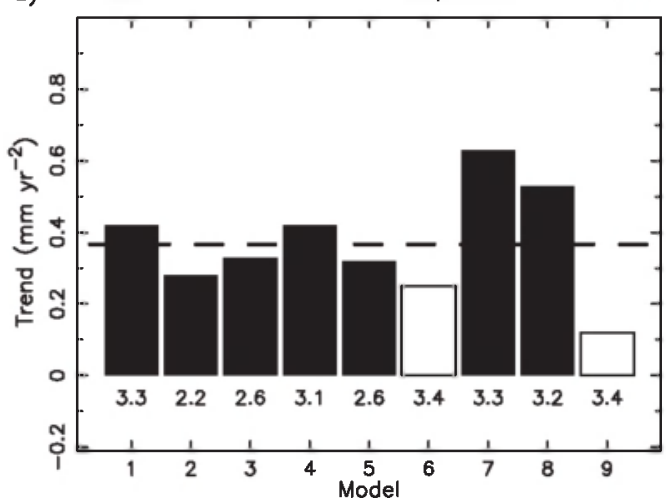

c) Trend in Annual Pan-Arctic Evapotranspiration, 1950-1999

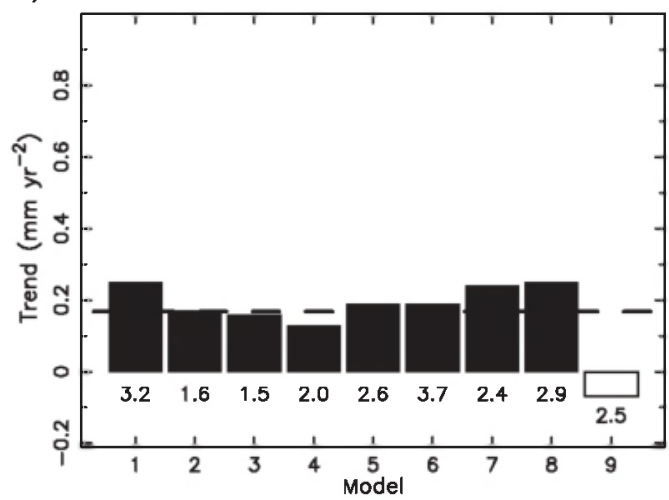

b) Trend in Annuol Pan-Arctic Precipitation, 1950-2049

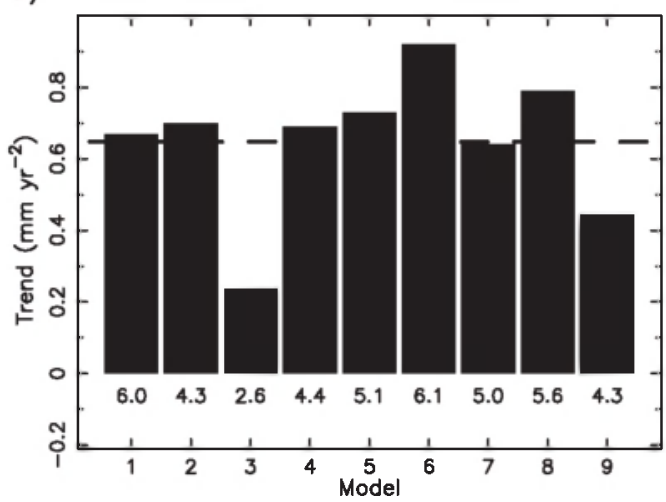

d) Trend in Annual Pan-Arctic Evapotronspiration, 1950-2049

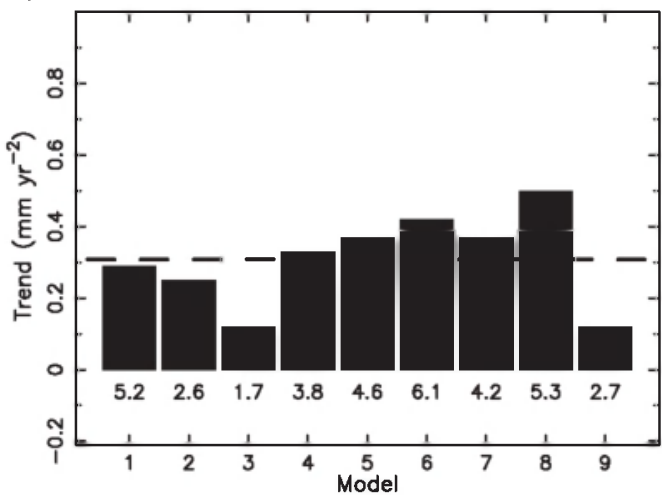

FIG. 4. Trends in (top) precipitation and (bottom) evapotranspiration averaged over the terrestrial pan-Arctic drainage basin for the periods (left) 1950-99 and (right) 1950-2049 from the nine GCMs. Filled rectangles represent the trend slope magnitudes for the models with a significant trend. The dashed line in each panel marks the multimodel mean trend magnitude. CV (in percent) for each GCM time series is indicated below the respective vertical bar.

drainage of North America, each in northern Alaska. Likewise, the Long-Term Ecological Research (LTER) network contains two Arctic sites, again both in Alaska. In situ ET measurement networks are similarly sparse for the Eurasian portion of the pan-Arctic. Given this data void, our analysis of ET trends involves information from land surface models and remote sensing data. ET is defined here as the total flux from all sources such as open water evaporation, transpiration from vegetation, and sublimation from snow.

Eddy covariance measurements are the primary means of observing turbulent, boundary layer ET fluxes. For regional- and continental-scale studies, models forced with time-varying climate data (e.g., precipitation and air temperature) must be used. The Variable Infiltration Capacity (VIC) hydrologic model (Liang et al. 1994) is a large-scale land surface model that solves for closure of the water and energy balance equations. It has been used in a variety of studies, both globally and across the pan-Arctic. ET is modeled using the Penman-Monteith equation, with resistances adjusted to account for soil moisture availability, temperature, radiation, and vapor pressure deficit. VIC contains a frozen soils scheme and a two-layer, physically based snow model (Cherkauer

TABLE 4. Trend magnitudes $\left(\mathrm{mm} \mathrm{yr}^{-2}\right)$ for $P$, ET, and $P$ - ET for the terrestrial pan-Arctic over the period $1950-99$ from the nine GCMs. Multimodel mean trend is shown in the last column, with the mean trend over the longer 1950-2049 period in (). Trends significant at $90 \%$ confidence level are indicated in bold.

\begin{tabular}{lccccccccrr}
\hline \hline \multicolumn{1}{c}{ Field } & 1 & 2 & 3 & 4 & 5 & 6 & 7 & 8 & 9 & Mean \\
\hline$P$ (Land) & $\mathbf{0 . 4 2}$ & $\mathbf{0 . 2 8}$ & $\mathbf{0 . 3 3}$ & $\mathbf{0 . 4 2}$ & $\mathbf{0 . 3 2}$ & 0.25 & $\mathbf{0 . 6 3}$ & $\mathbf{0 . 5 3}$ & 0.12 & $\mathbf{0 . 3 7}(\mathbf{0 . 6 5})$ \\
ET (Land) & $\mathbf{0 . 2 5}$ & $\mathbf{0 . 1 7}$ & $\mathbf{0 . 1 6}$ & $\mathbf{0 . 1 3}$ & $\mathbf{0 . 1 9}$ & $\mathbf{0 . 1 9}$ & $\mathbf{0 . 2 4}$ & $\mathbf{0 . 2 5}$ & -0.07 & $\mathbf{0 . 1 7}(\mathbf{0 . 3 1})$ \\
$P-$ ET (Land) & $\mathbf{0 . 1 6}$ & 0.10 & $\mathbf{0 . 1 7}$ & $\mathbf{0 . 2 9}$ & 0.13 & 0.06 & $\mathbf{0 . 3 9}$ & $\mathbf{0 . 2 8}$ & 0.19 & $\mathbf{0 . 2 0}(\mathbf{0 . 3 4})$ \\
\hline
\end{tabular}


et al. 2003). Model parameters are calibrated to match large basin discharge. Simulations show that VIC streamflow estimates compare well to gauge observations across northern Eurasia and North America. Trends in ET were taken from a VIC simulation that was performed at a 6-h time step over the pan-Arctic domain with forcing from the S06 dataset. Annual total ET from a suite of five LSMs (including the VIC model) forced with data from the ERA-40 reanalysis (European Centre for Medium-Range Weather Forecasts 2002) are also examined here for trends. The simulations were made on a $100-\mathrm{km}$ grid across the pan-Arctic drainage basin as described by Slater et al. (2007). For each model, panArctic ET is derived from the spatial grids within the Arctic drainage basin, with the mean model trend drawn from the five-model ET averages.

Estimates of ET at regional and global scales are also available through satellite remote sensing. These methods are generally based on surface energy balance partitioning among sensible heat, latent heat, and soil heat-heat storage fluxes. For this study we derive remote sensing (RS)-based ET (monthly, 1983-2005) using the Penman-Monteith approach by incorporating biomespecific environmental stress factors and satellite-derived radiation and vegetation information ( $\mathrm{Mu}$ et al. 2007; Zhang et al. 2009). The model employs the National Aeronautics and Space Administration-Global Energy and Water Cycle Experiment (NASA-GEWEX) solar radiation and albedo inputs, the Advanced Very High Resolution Radiometer (AVHRR) Global Inventory Modeling and Mapping Studies (GIMMS) normalized difference vegetation index (NDVI), and regionally corrected NCEP-NCAR reanalysis daily surface meteorology (Zhang et al. 2008, 2009). The ET estimates, originally produced at a daily time step and 8 -km spatial resolution, were reprojected to the National Snow and Ice Data Center (NSIDC) $12.5-\mathrm{km}$-resolution Equal-Area Scalable Earth Grid (EASE-Grid).

Figure 5 shows annual ET from the sources described above. Annual ET from VIC shows a significant upward trend from 1950 through 1999 of $0.11 \mathrm{~mm} \mathrm{yr}^{-2}$ (Table 2). The mean trend $\left(0.40 \mathrm{~mm} \mathrm{yr}^{-2}\right)$ among the LSMs of Slater et al. (2007) also suggests ET intensification. As mentioned above, these model simulations were forced with precipitation and air temperature from the ERA-40 reanalysis. ERA-Interim ET data also exhibit an upward tendency, which is not significant. This result is largely attributable to the short time period, as the $\mathrm{CV}$ $(2.5 \%)$ is not particularly high. From 1983 through 2005 , the AVHRR GIMMS-based ET trend is $0.38 \mathrm{~mm} \mathrm{yr}^{-2}$, nearly identical to the trend from the five LSMs. This is noteworthy given that the AVHRR GIMMS ET is not dependent on forcing or assimilation of precipitation. The

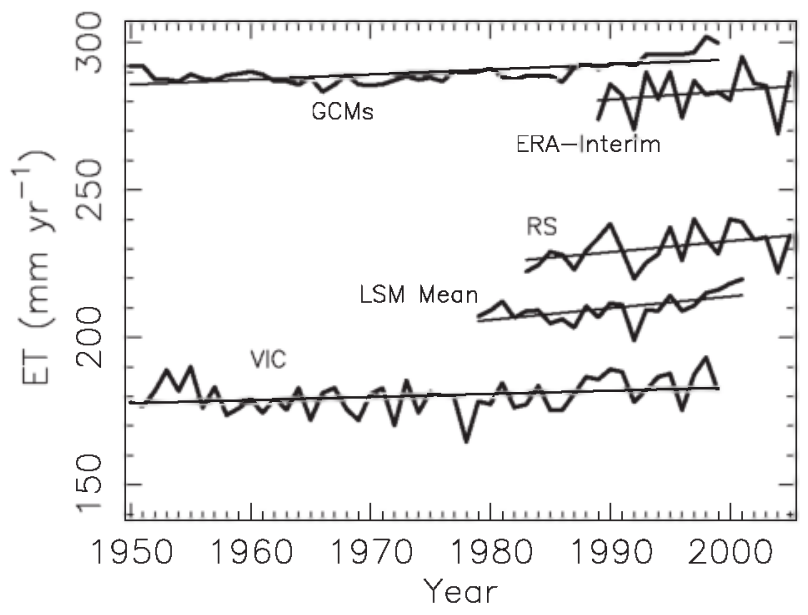

FIG. 5. Annual evapotranspiration for the terrestrial region (light + dark gray) shown in Fig. 1. Time series depicted are from the nine GCMs, the mean among the five LSMs, the surface energy balance and RS method, VIC model, and the ERA-Interim dataset.

AVHRR GIMMS ET estimates agree well (RMSE = $6.3 \mathrm{~mm} \mathrm{month}^{-1} ; R^{2}=0.91$ ) with observed fluxes from eight independent regional flux towers representing regionally dominant land cover types (Zhang et al. 2009). All of the ET estimates in Table 3 have magnitudes that are considerably lower than the best estimate from Serreze et al. (2006), which is approximately $310 \mathrm{~mm} \mathrm{yr}^{-1}$. It has been suggested that ERA-40 ET is about $30 \%$ higher than observations (Betts et al. 2003). Although the magnitude of VIC ET is clearly low, we have no reason to assume that the associated ET trend should be discounted. Taken together, these varied data suggest that ET has increased over recent decades. Further investigation is required to determine whether the upward trends are a manifestation of increases in precipitation, increases in air temperature, and/or a lengthened growing season, which advanced by approximately 7 days from 1988 to 2001 across the northern Eurasian panArctic basin (McDonald et al. 2004). Twentieth-century trends in climate warming have resulted in a lengthening of the growing season across northern temperate latitudes (Menzel and Fabian 1999; Frich et al. 2002; Schwartz et al. 2006). A longer growing season is likely to result in continued upward trends in ET, provided that moisture is not limiting (Huntington 2004).

Similar to the precipitation analysis, annual ET series from the GCMs (Figs. 3 and 4c) also exhibit positive trends, with the exception of the GFDL CM2.1 model (Table 4), and all but the GFDL CM2.1 show significant trends. Trend magnitudes vary across a fairly narrow range from -0.07 to $0.25 \mathrm{~mm} \mathrm{yr}^{-2}$. The multimodel mean trend (1950-99) is $0.17 \mathrm{~mm} \mathrm{yr}^{-2}$, generally lower than the trend from several of the land surface ET data 
and less than half of the mean trend among the five LSMs forced with ERA-40 climate. Several of our modeled ET series begin in the $1980 \mathrm{~s}$, and their sharper trends suggest a more amplified increase, relative to the GCMs, over recent decades. Like precipitation, the GCM multimodel ET trend over the 100-yr period $\left(0.31 \mathrm{~mm} \mathrm{yr}^{-2}\right)$ is greater than the trend from 1950 through 1999 by more than $80 \%$ (Table 4). Like precipitation, consistency in the significance of the GCM ET trends is noteworthy.

\section{c. River discharge and net precipitation}

Among all Arctic FWC components, discharge from large rivers draining into the Arctic Ocean is one of the most well observed. River discharge is the result of many processes such as precipitation, ET, soil infiltration, and permafrost dynamics, which vary across a watershed. River flow is typically calculated on a daily basis from water stage observations (water height) and established long-term stage-discharge relationships. These relationships are regularly updated using actual discharge measurements. High-latitude rivers have, however, long ice-covered periods (up to 7-8 months) when the use of an open channel stage-discharge relationship is limited or impossible, and the accuracy of discharge estimates during these periods is significantly lower and strongly depends on the frequency of discharge measurements (Shiklomanov et al. 2006). Substantial ice thickness, cold weather, and low river velocity under the ice reduce the accuracy of measurements (Prowse and Ommaney 1990). During the transitional periods of river freeze and breakup, the uncertainty of daily discharge records for large Arctic rivers can exceed $30 \%$. Annual discharge estimates, however, carry uncertainties of approximately $3 \%-8 \%$ (Shiklomanov et al. 2006), considerably smaller than those associated with gauge-based precipitation (Goodison et al. 1998; Yang et al. 2005).

River discharge is often affected by direct human impacts including water withdrawals and intraannual discharge redistribution by dams. This fact dictates that hydroclimatological analysis of river discharge temporal trends must consider how human impacts can affect the trends. River discharge from Eurasia, particularly from the Yenisey basin, is affected by several major hydroelectric dams that were constructed beginning in the late 1950s. Of all seasons, winter discharge trends can be particularly difficult to estimate (Ye et al. 2003; McClelland et al. 2004; Adam et al. 2007; Shiklomanov and Lammers 2009). While annual trends are less affected, a study using reconstructed data suggests that dams may be obscuring naturally occurring trends for heavily regulated parts of watersheds (Ye et al. 2003; Yang et al. 2004a,b; Shiklomanov and Lammers 2009). Additionally, declines in the number of operational gauging stations have occurred since the mid-1990s (Shiklomanov et al. 2000, 2002), and this has reduced the accuracy of the estimates of river discharge to the Arctic Ocean. Our examination of precipitation and ET trends involves pan-Arctic integrations from gridded fields. In contrast, river discharge trends are derived from point observations. These observations, however, represent integrative measures of hydrological processes over the upstream catchment regions. A significant portion of the pan-Arctic basin has lacked routine monitoring. Therefore, we apply discharge estimates from monitored watersheds to ungauged regions using the hydrological analogy approach to estimate total discharge to the Arctic Ocean (or Hudson Bay) from large drainage areas and to provide consistency for the integrated analysis of trends in other water balance components. Estimates of river runoff based on the analysis of water balance components made at the State Hydrological Institute (SHI) in St. Petersburg, Russia, similar to estimates used in "World Water Balance and Water Resources" (Korzun 1978), are used here for unmonitored areas where the analogy approach is not applicable.

Records of river discharge for the largest rivers are taken from version 4.0 of the Regional, Electronic, Hydrographic Data Network (R-ArcticNet) database (available online at http://www.r-arcticnet.sr.unh.edu/) and updated up to 2004 (Lammers et al. 2001; Shiklomanov et al. 2002). Our analysis includes all land areas that drain to the Arctic Ocean, Hudson Bay, and Bering Strait. In addition to the entire pan-Arctic drainage basin, we also analyze discharge from Eurasia, North America, and the region draining to Hudson Bay.

From 1950 through 2004, annual pan-Arctic discharge exhibits a significant, positive trend of $0.23 \mathrm{~mm} \mathrm{yr}^{-2}$ $\left(5.3 \mathrm{~km}^{3} \mathrm{yr}^{-2}\right)$, significant at the $90 \%$ confidence level (Fig. 6; Table 2). The majority of river flow to the Arctic Ocean originates from Eurasia, a region with long records relative to North America. River discharge from the six largest Eurasian river basins has exhibited a sustained long-term increase over the past $70+$ yr (Peterson et al. 2002; Shiklomanov and Lammers 2009). This is reflected in the greater trend $\left(0.31 \mathrm{~mm} \mathrm{yr}^{-2}\right)$ for Eurasia compared to the pan-Arctic trend. In contrast to the increased flow for Eurasia, no significant change is evident for the Arctic drainage of North American as a whole over the same period. However, when the flow to Hudson Bay is excluded, a large significant increase $\left(0.40 \mathrm{~mm} \mathrm{yr}^{-2}\right)$ emerges. In turn, estimates for Hudson Bay from 1950 through 2005 exhibit no trend. Other studies have noted significant declines in the flow to Hudson Bay since 1964 (Déry et al. 2005; McClelland et al. 2006). More recent data (1989-2007), however, show a $15.5 \%$ increase in the annual flows from Canada along 


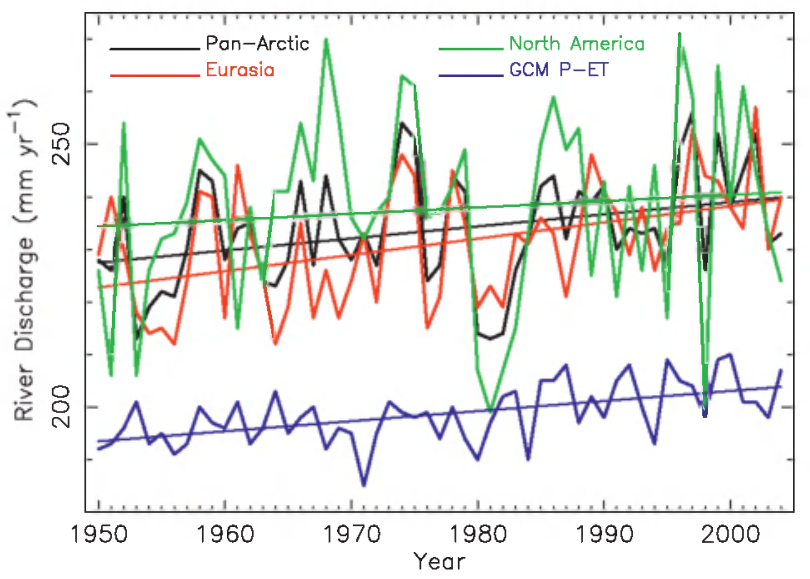

FIG. 6. Annual river discharge for the pan-Arctic (including ungauged areas), the six largest Eurasian basins, North America, and multimodel mean $P-$ ET, 1950-2004. Trend magnitude and statistical significance are shown in Table 2. For consistency with Figs. 3 and 4, the GCM trend and CVs in Table 2 are calculated over the 50 -yr period 1950-99. The domain for the GCMs (shown in Fig. 1) differs from the pan-Arctic domain as described in section 2.

with an increase in variability, indicative of intensification (Déry et al. 2009). Increases of 5\%-35\% in annual precipitation across Canada from 1950 through 1998 have also been reported (Zhang et al. 2000). Trends described here are broadly consistent with results from several recent studies for Eurasia and North America (Yang et al. 2004a,b; Déry et al. 2005; McClelland et al. 2006).

Analysis of $P-$ ET produced by the difference of precipitation (GPCP and GPCC) and AVHRR GIMMSbased ET reveals no significant trend. Despite the fact that both GPCP and GPCC precipitation exhibit increases greater than those for ET, the trend in $P-\mathrm{ET}$ is not statistically significant. In essence, high variability (CVs 5.6\% and 5.8\%; Table 2) obscures the trend signals. This also occurs with $P-$ ET (1979-2007) from the Japanese 25-yr Reanalysis (JRA-25), which has tended to increase but over a time period too short to yield a significant change. Indeed, while $\mathrm{CVs}$ for all river discharge records are higher than those for the precipitation and ET series, long time periods along with the strength of the trend enable the pan-Arctic, North America excluding drainage to Hudson Bay, and, most notably, Eurasian basin trends to reach the $90 \%$ confidence level. Regarding attribution, positive trends in $P$ - ET have been shown to be correlated with the Arctic Oscillation-North Atlantic Oscillation (AO-NAO; Groves and Francis 2002). This association, however, was derived from precipitable water retrieved from satellite data and reanalysis and was made from 1980 through 1999, and it is impossible to draw conclusions for the period since 1950. Mean $P$ - ET among the GCMs
(220 $\mathrm{mm} \mathrm{yr}^{-1}$ ) differs from pan-Arctic river discharge (runoff) by $<5 \%$, but it is notably higher than the estimate compiled by Serreze et al. (2006) of $180 \mathrm{~mm} \mathrm{yr}^{-1}$.

As with the GCM precipitation and ET series, $P-$ ET exhibits increases over the 1950-99 period. Fewer (five of nine) of the GCM $P-$ ET series, however, show significant increases than the GCM precipitation or ET series (Table 4). Increases in precipitation generally outpace those from ET, consistent with observations for the major rivers of the conterminous United States (Walter et al. 2004). The multimodel mean trend (195099) is $0.20 \mathrm{~mm} \mathrm{yr}^{-2}$, slightly less than the observed panArctic river discharge trend of $0.23 \mathrm{~mm} \mathrm{yr}^{-2}$. Like precipitation and ET, GCM trends $\left(0.06-0.39 \mathrm{~mm} \mathrm{yr}^{-2}\right)$ extend over a more limited range than the river discharge and other observed $P$ - ET trends. Over the 1950-2049 period, trends in GCM net precipitation range from 0.12 to $0.51 \mathrm{~mm} \mathrm{yr}^{-2}$, with a multimodel mean trend of $0.34 \mathrm{~mm} \mathrm{yr}^{-2}$. Net precipitation increases by $18 \%$ based on the multimodel mean trend over the $1950-2049$ period. The change is only $5 \%$ for $1950-99$, suggesting an acceleration in net precipitation over time. In short, precipitation increases outpace ET increases, suggesting continued future net precipitation intensification.

\section{d. Associated terrestrial water cycle components}

Changes in other water cycle components, while not fitting our strict definition of intensification, are particularly relevant. A decline in lake abundance and area has been noted throughout the region of discontinuous, sporadic, and isolated permafrost of Siberia, while increases in lake area and number have occurred across the continuous permafrost (Smith et al. 2005a). From 1972 through 2006, snow cover extent (SCE) declined significantly during spring across both North America and Eurasia, with lesser declines during winter and some increases during fall (Déry and Brown 2007). Although snow cover extent has generally decreased (Brown and Goodison 1996; Robinson and Frei 2000; Serreze et al. 2000), there are signs that Eurasia has experienced significant increases in snow depth (Ye et al. 1998; Bulygina et al. 2009) and winter precipitation (Yang et al. 2002; Frey and Smith 2003; Serreze et al. 2002; Rawlins et al. $2006,2009 \mathrm{~b}$ ). Taken together, the studies suggest lower seasonal freshwater storages at the southern margins of the pan-Arctic basin, with increases over northern Eurasia. Increasing winter precipitation would tend to result in increased runoff during the melt season over permafrost regions where infiltration rates are lower. Glaciers across many regions are losing mass as a result of warming, with rapid losses of ice volume since around 1990 (Dyurgerov and Meier 2000, 2005). These Arctic 
glacier trends are generally consistent with global declines but quantitatively smaller, and the contribution of glacier melt to river flow across the pan-Arctic is small. Other major changes include a lengthening of the growing season, which may be an important component in the upward ET trend. Estimates from remote sensing and $\mathrm{CO}_{2}$ flask measurements suggest an advance in growing season from 1.5 to 4 days per decade (McDonald et al. 2004; Zhang et al. 2009).

Observed evidence of changes in active layer thickness (ALT) and permafrost conditions is substantial worldwide. Permafrost temperatures have increased up to $3^{\circ} \mathrm{C}$ during the past several decades across parts of the terrestrial pan-Arctic (Osterkamp 2005; Smith et al. 2005b; Pavlov 1994; Oberman and Mazhitowa 2001). Changes in air temperature alone cannot account for the permafrost temperature increase, which suggests that changes in seasonal snow cover conditions may also be involved (Zhang and Osterkamp 1993; Zhang 2005). Based on soil temperature measurements in the active layer and upper permafrost up to $3.2 \mathrm{~m}$ from 37 hydrometeorological stations in Russia, the active layer exhibited a statistically significant deepening of about $25 \mathrm{~cm}$ from the early 1960s to 1998 (Frauenfeld et al. 2004; Zhang et al. 2005). The International Permafrost Association (IPA) started a network of the Circumpolar Active Layer Monitoring (CALM) program in the 1990s to monitor the response of the active layer and upper permafrost to climate change and currently incorporates more than 125 sites worldwide (Brown et al. 2000). The results from high-latitude sites in North America demonstrate substantial interannual and interdecadal fluctuations but with no significant trend in ALT in response to increasing air temperatures. Evidence from the CALM European monitoring sites suggests that ALT was greatest in the summers of 2002 and 2003 (Harris et al. 2003). ALT has increased by up to $1.0 \mathrm{~m}$ over the QinghaiTibetan Plateau since the early 1980s (Zhao et al. 2004).

The effect of increasing ALT on the Arctic FWC is complicated. Freezing of soil moisture reduces the soil hydraulic conductivity, leading to either more runoff due to decreased infiltration or higher soil moisture content due to restricted drainage. The existence of a thin frozen layer near the surface decouples soil moisture exchange between the atmosphere and deeper soils (Zhang et al. 2005; Ye et al. 2009). Permafrost essentially limits the amount of subsurface water storage and infiltration that can occur, leading to wet soils and ponded surface waters, unusual for a region with such limited precipitation. An increase in ALT, on one hand, directly increases groundwater storage capacity and thus reduces river discharge through partitioning of surface runoff from snowmelt and/or rainfall. On the other hand, melting of excess ground ice near the permafrost surface can contribute water to runoff and potentially increase river discharge. In this case, less ice would tend to result in more moisture available for evaporation and transpiration compared to a thinner ALT and a longer period of frozen surface soil. Changes in the movement of water within the soil column may be occurring. Increases in thaw depth and, in turn, soil water flowpaths have been inferred from geochemical tracers in Alaskan North Slope streams (Keller et al. 2010). Model studies point to potentially large future increases in river discharge because of permafrost thaw (Lawrence and Slater 2005). The net effect of this change on river discharge thus requires further study and long-term monitoring.

\section{Marine system}

\section{a. Freshwater exchanges with the Atlantic and Pacific Oceans}

We consider in this section the inflows and outflows of liquid (ocean) freshwater as well as the solid (sea ice) component. The inflows occur in the Bering Strait, the eastern side of Fram Strait, and the Barents Sea (ice only). Outflows occur through the Canadian Arctic Archipelago, the western side of Fram Strait, and the Barents Sea (ocean only). All freshwater fluxes are calculated relative to a salinity of 34.8 , except where noted.

\section{1) Fram STRAIT ICE FLUX}

The mean annual ice concentration-weighted area outflow at the Fram Strait over the period 1979-2007 has been computed using satellite data as $(706 \pm 113) \times$ $10^{3} \mathrm{~km}^{2}$. There is no statistically significant long-term trend in the Fram Strait area flux in the 29-yr record, a reflection of an increasing cross-strait sea level pressure gradient (i.e., stronger local winds) and a decreasing ice concentration (Kwok 2009). Turning to volume flux, the best estimate of the mean annual volume flux using satellite and mooring data between 1991 and 1999 is $\sim 2200 \mathrm{~km}^{3} \mathrm{yr}^{-1}\left[\sim 0.07 \mathrm{~Sv}\left(1 \mathrm{~Sv} \equiv 10^{6} \mathrm{~m}^{3} \mathrm{~s}^{-1}\right)\right.$; Kwok et al. (2004)], or $\sim 0.3 \mathrm{~m}$ of Arctic Ocean sea ice (area of 7.2 million $\mathrm{km}^{2}$ ). It is not readily apparent from this short 9-yr record that there is any discernible trend in annual ice volume exiting the Fram Strait. A recent update by Spreen et al. (2009) also finds no trend.

On average, the IPCC models (Fig. 7) show higher area outflow and lower ice concentration in the Fram Strait than observational estimates. However, in agreement with the 29 -yr observational record, there is no trend in the model simulations of area outflow. Even though the average model behavior does not show a negative trend in the ice concentration during the period 

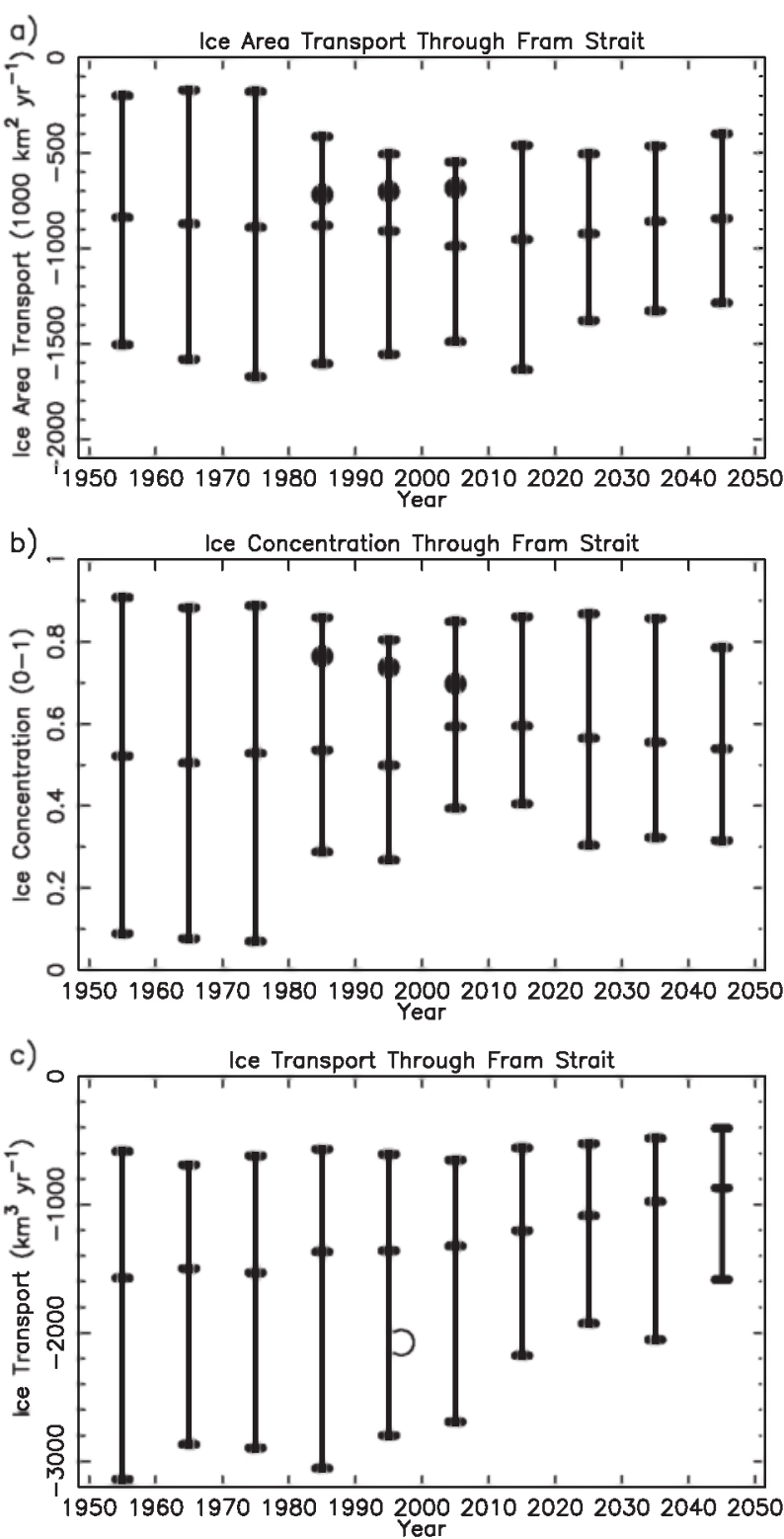

FIG. 7. Decadal mean, minimum, and maximum (horizontal tick marks) (a) ice area transport, (b) ice concentration, and (c) ice volume transport across Fram Strait from the nine GCMs. Observational data from satellites are shown by the black dots in (a) and (b) and from in situ ice-thickness sonars by the open circle in (c). Table 1 indicates the ocean fields simulated by each of the nine models.

of the satellite record, there is a noticeable trend after 2000 . This can be seen in the decline in volume outflow at the Fram Strait. The average model estimates of sea ice volume outflow are lower than those from observational estimates by approximately one-quarter of the annual mean (or $\sim 500 \mathrm{~km}^{3}$ ). This could be significant in terms of simulating the survivability and decline of the ice cover, and it could be one of the factors contributing to the slower reduction in Arctic ice extent produced by model projections (compared to that observed) reported by Stroeve et al. (2007).

\section{2) FRAM STRAIT OCEAN FRESHWATER FLUX}

Prior to 1980, only sporadic hydrographic sections across Fram Strait were available. Östlund and Hut (1984) used $\delta^{18} \mathrm{O}$ measurements to determine an ocean freshwater export of $4730 \mathrm{~km}^{3} \mathrm{yr}^{-1}$. Generally lower values of $883-2996 \mathrm{~km}^{3} \mathrm{yr}^{-1}$ were obtained using salinity data from hydrographic surveys by Aagaard and Carmack (1989) and Rudels et al. (2008). Holfort and Hansen (2005) used data extending from the deep water in the east westward across the Greenland shelf and proposed a total mean freshwater transport of $1987 \mathrm{~km}^{3} \mathrm{yr}^{-1}$, with $40 \%$ of this occurring on the shelf. In the mid-1980s, a mooring array at $79^{\circ} \mathrm{N}$ was deployed for $2 \mathrm{yr}$ and then from 1997 onward a more extensive array has been deployed (although no moorings have been deployed on the broad East Greenland shelf). Using salinity and direct velocity data from these moorings, Holfort et al. (2008) derived a freshwater transport similar to that found by Holfort and Hansen (2005). It should be noted that most recent studies have used reference salinities of 34.9 , which produce about $10 \%$ higher freshwater fluxes relative to those calculated using a reference salinity of 34.8. Recently, de Steur et al. (2009) combined the mooring and hydrographic survey data to show that although there is interannual variability, no long-term trend in Fram Strait southward liquid freshwater transport can be determined over the period 1997-2007. This is in contrast to an increase in this quantity simulated by many climate models from 1950 to 2050 (Holland et al. 2007; see their Fig. 12a). However, given intrinsic low-frequency variability in ocean transport, it is likely that the observed time series is too short to assess a forced trend. Additionally, the observational knowledge of the liquid freshwater transport through Fram Strait is still uncertain, owing to a lack of knowledge about conditions on the East Greenland shelf and also the undersampling of the surface fresh layer by moorings.

What does the future hold? Holland et al. (2007) predict that the liquid freshwater content of the Arctic Ocean will increase in the coming years. If we assume that the freshwater export in the East Greenland Current is largely carried by the resulting baroclinic geostrophic flow, then this flow should increase, as seen in Holland's model analysis.

\section{3) BARENTS SEA ICE FLUX}

For sea ice, this flux has been computed at the northern boundary of the Barents Sea, that is, across the 
passages between Svalbard and Franz Josef Land (S-FJL) and between Franz Josef Land and Severnaya Zemlya (FJL-SZ). In the 29-yr record of ice area flux from satellite estimates (Kwok 2009), there is a mean annual inflow to the Arctic Ocean of seasonal ice through the FJL-SZ passage of $(103 \pm 93) \times 10^{3} \mathrm{~km}^{2}$. The source of this sea ice is the Barents Sea as well as the Kara Sea. The annual outflow at the S-FJL passage is $(37 \pm 39) \times$ $10^{3} \mathrm{~km}^{2}$ - that is, $\sim 5 \%$ of the Fram Strait area export, with no statistically significant trend. The result is a net inflow of sea ice to the Arctic Ocean of $66 \times 10^{3} \mathrm{~km}^{2}$, with no trend. Thus, the Barents Sea is a net producer of sea ice, which is exported northward to the Arctic Ocean. This ice presumably is swept into the sea ice circulation that exits the Arctic Ocean via Fram Strait.

\section{4) BARENTS SEA OCEAN FRESHWATER FLUX}

The oceanic freshwater flux has been monitored at the western boundary of the Barents Sea across longitude $20^{\circ} \mathrm{E}$. The fluxes are composed of contributions from the relatively fresh eastward-flowing Norwegian Coastal Current (NCC), the relatively saline Atlantic inflow with the North Cape Current $(\mathrm{NCaC})$, and the outflowing recirculated Atlantic water in the Bear Island Trough (BIT) (Björk et al. 2001; Skagseth et al. 2008). The hydrographic variations of these branches have been monitored somewhat sporadically since the 1960 s and regularly since 1977 (4-6 times per year). Since 1997, these measurements have been complemented with an array of current-meter moorings. For the $\mathrm{NCaC}$ and the BIT outflow, the annual mean volume fluxes are combined with the observed deseasoned long-term core salinities to obtain the freshwater fluxes. The freshwater flux in the NCC is estimated based on vertical profiles by assuming geostrophic balance, with a zero velocity reference assumed at a density outcrop (Orvik et al. 2001). The baroclinic transport is then combined with vertical profiles of salinity to get the freshwater flux.

The total and individual contributions to the freshwater are summarized in Table 5. In total, there is a freshwater outflow of $84 \mathrm{~km}^{3} \mathrm{yr}^{-1}$, which is the sum of a large $\mathrm{NCaC}$ outflow (i.e., inflowing water saltier than the reference salinity) and two smaller inflows from the NCC and from the Bear Island Trough recirculation. There is a long-term decrease in the total outflow from $115 \mathrm{~km}^{3} \mathrm{yr}^{-1}$ for the period 1965-84 compared to $55 \mathrm{~km}^{3} \mathrm{yr}^{-1}$ for the period 1985-2005. This is due to an increased NCC freshwater inflow associated with increased precipitation over northern Europe and Scandinavia.

An anticipated future warming and more atmospheric moisture content will probably act to continue the freshening of the NCC. On the other hand, the freshwater
TABLE 5. Freshwater fluxes (relative to a salinity of 34.8) across $20^{\circ} \mathrm{E}$ in the two inflowing currents (Norwegian Coastal Current and North Cape Current) and the outflowing recirculation in the Bear Island Trough. Positive values indicate freshwater inflow to the Barents Sea.

\begin{tabular}{lccc}
\hline \hline & \multicolumn{3}{c}{ Freshwater flux $\left(\mathrm{km}^{3} \mathrm{yr}^{-1}\right)$} \\
\cline { 2 - 4 } & $\begin{array}{c}\text { Mean } \\
1965-2005\end{array}$ & $\begin{array}{c}\text { Mean } \\
1965-84\end{array}$ & $\begin{array}{c}\text { Mean } \\
1985-2005\end{array}$ \\
\hline Norwestern Coastal Current & 246 & 197 & 294 \\
North Cape Current & -502 & -484 & -519 \\
Bear Island Trough & 172 & 173 & 170 \\
Total & -84 & -115 & -55 \\
\hline
\end{tabular}

fluxes associated with the $\mathrm{NCaC}$ and the Bear Island Trough recirculation are dependent on the local regional wind forcing (Ingvaldsen et al. 2002) as well the salinity of the Atlantic water. Future trends in these variables are very uncertain.

\section{5) BERING Strait ICE FluX}

Initial work (Aagaard and Carmack 1989) estimated the Bering Strait freshwater flux from ice as an inflow to the Arctic Ocean of $24 \mathrm{~km}^{3} \mathrm{yr}^{-1}$. The present best observational estimate is an inflow of $100 \pm 70 \mathrm{~km}^{3} \mathrm{yr}^{-1}$, assuming a sea ice salinity of 7 psu (Woodgate and Aagaard 2005), although this is highly speculative, being based on the extrapolation of data of ice thickness and ice motion from one mooring in the center of the strait. No long-term trends have been computed. Comparison of modeled ice freshwater fluxes (not shown) shows a greater spread than the oceanic freshwater flux (next section). In particular, the three models that simulate the most realistic Bering Strait ocean freshwater flux differ in sign for the ice freshwater flux.

\section{6) BERING STRAit OCEAN FRESHWATER FLUX}

A 14-yr (1990-2004) dataset of year-round nearbottom measurements in the Bering Strait was combined by Woodgate and Aagaard (2005) with estimates of sea ice flux and freshwater transport within the Alaskan Coastal Current (ACC) and in the summer stratified surface layer to yield a 14-yr mean ocean freshwater transport of $2500 \pm 300 \mathrm{~km}^{3} \mathrm{yr}^{-1}$. Interannual variability in the observational estimates is substantial. Without considering the contributions from the $\mathrm{ACC}$ or stratification [likely adding $\sim(800-1000) \mathrm{km}^{3} \mathrm{yr}^{-1}$ ], annual mean freshwater transport through the Bering Strait is estimated to vary between $\sim 1400$ and $2000 \mathrm{~km}^{3} \mathrm{yr}^{-1}$, with lows in the early 2000s (Woodgate et al. 2006). It is noteworthy that the freshwater increase between 2001 and 2004 is $\sim 800 \mathrm{~km}^{3}$, about one-quarter of annual Arctic river runoff. About $80 \%$ of the increase in freshwater can 
be accounted for by the increased volume flux over the same time period, which in turn may be related to changes in the local wind.

Coupled model simulations of the oceanic Bering Strait freshwater flux vary widely (not shown). However, the multimodel ensemble mean produces a longterm mean value close to observations, also reproduced by the Canadian Centre for Climate Modelling and Analysis (CCCma) Coupled General Circulation Model, version 3.1 (CGCM3.1), the Model for Interdisciplinary Research on Climate 3.2 (MIROC3.2), and CCSM3 individual runs. Modeled long-term trends are small (Holland et al. 2007; their Fig. 8), with changes of $\sim 200 \mathrm{~km}^{3} \mathrm{yr}^{-1}$ over a 100 -yr period. This change is generally smaller than the observed interannual variability over 1990-2004.

\section{7) CANAdian ARCHIPELAGO ICE FLUX}

Over the period between 1997 and 2002, high-resolution radar imagery in the western archipelago (Kwok 2006) has been used to estimate mean annual sea ice areal fluxes through the Amundsen Gulf, M'Clure Strait, and the Queen Elizabeth Islands of $(85 \pm 26) \times 10^{3},(20 \pm$ 24) $\times 10^{3}$, and $-(8 \pm 6) \times 10^{3} \mathrm{~km}^{2}$ (negative sign indicates outflow). Overall, sea ice is imported from the Canadian Archipelago into the Arctic Ocean in this area, providing a volume inflow of roughly $100 \mathrm{~km}^{3} \mathrm{yr}^{-1}$. This is balanced by the export of Arctic Ocean sea ice through Nares Strait in the northeastern archipelago. Kwok et al. (2005) computed an average annual (September-August) ice area outflow of $33 \mathrm{~km}^{3}$ across the $30-\mathrm{km}$-wide northern entrance at Robeson Channel. Thick, multiyear ice coverage in Nares Strait is high $(>80 \%)$, with volume outflow estimated to be $\sim 100 \mathrm{~km}^{3} \mathrm{yr}^{-1}$ - that is, $\sim 5 \%$ of the mean annual Fram Strait ice flux and exactly opposite to the inflow calculated for the western archipelago. However, it is important to note that these short time series may not be representative of the long-term balance, and they have not yet been used to calculate long-term trends. An interesting recent phenomenon is the failure of winter ice arches to form within Nares Strait, which if this continues would sustain the export of very thick ice from the Arctic Ocean.

\section{8) CANAdian ARCHiPELAGo OCEAN FRESHWATER FLUX}

Total ocean freshwater transport through the various straits of the Archipelago has been estimated using historical data as roughly $(900-4000) \pm 1000 \mathrm{~km}^{3} \mathrm{yr}^{-1}$ (Aagaard and Carmack 1989; Tang et al. 2004; Cuny et al. 2005; Dickson et al. 2007; Serreze et al. 2006), with more recent efforts placing tighter constraints on fluxes through the major passages of Nares Strait (Munchow et al. 2006) and Lancaster Sound (Prinsenberg and Hamilton 2005). An attractive option is to measure the flux across Davis Strait to the south, which theoretically should integrate all of these fluxes. Recent analysis of mooring data taken since 2004 (unpublished) indicates a decline in net southward freshwater flux, but this is not statistically significant. Most models analyzed by Holland et al. (2007) did not include an open Canadian Archipelago. However, the CCSM model analyzed by Holland et al. (2006) did provide flux estimates through this area. The model results (not shown) estimate freshwater fluxes of about $1388 \mathrm{~km}^{3} \mathrm{yr}^{-1}$ over the twentieth century, which is within the historical range.

\section{9) NET PRECIPITATION}

The $P-$ ET over the Arctic Ocean for the period 1979-2007, estimated from the atmospheric moisture budget (wind and vapor flux fields) of JRA-25, shows no trend. And while annual $P-\mathrm{ET}$ derived from precipitable water retrieved from the Television and Infrared Observation Satellite (TIROS) Operational Vertical Sounder (TOVS) and upper-level winds from the NCEPNCAR reanalysis suggest recent increases in Arctic Ocean net precipitation (1989-98 average versus 1980-88 average), the decadal difference is small $(4.2 \%$ of the 19-yr mean) and not statistically significant (Groves and Francis 2002).

\section{b. Freshwater storage within the Arctic Ocean}

\section{1) SEA ICE}

Rothrock et al. (2008) showed that over the period 1975-2000, annual mean Arctic Ocean sea ice thickness decreased by $1.25 \mathrm{~m}$ (i.e., $\sim 31 \%$ ), with the maximum thickness in 1980 and the minimum in 2000 . The sharpest rate of decline occurred in 1990, with a much slower rate by the end of the record. More recently, Giles et al. (2008) analyzed satellite-based radar altimeter data that indicate relatively constant ice thickness between 2003 and 2007 , followed by a substantial decrease between 2007 and 2008 .

The decline in ice freshwater storage is due to a combination of a loss of ice thickness and a loss of ice area. The estimated loss in thickness is on the order of $30 \%$ from 1975 to 2000 (Rothrock et al. 2008). Comiso and Nishio (2008) used passive microwave satellite data over 1979-2006 to estimate ice area loss as $2 \%$ per decade in winter and $9 \%$ in summer. Over the period from 1975 to 2000 the total loss in ice freshwater storage would therefore be on the order of $40 \%$. None of the coupled GCMs shown in Fig. 8 comes close to this. The largest decline over this period is around $25 \%$ in the CCSM3 and MIROC3.2 model runs. The average of all the 


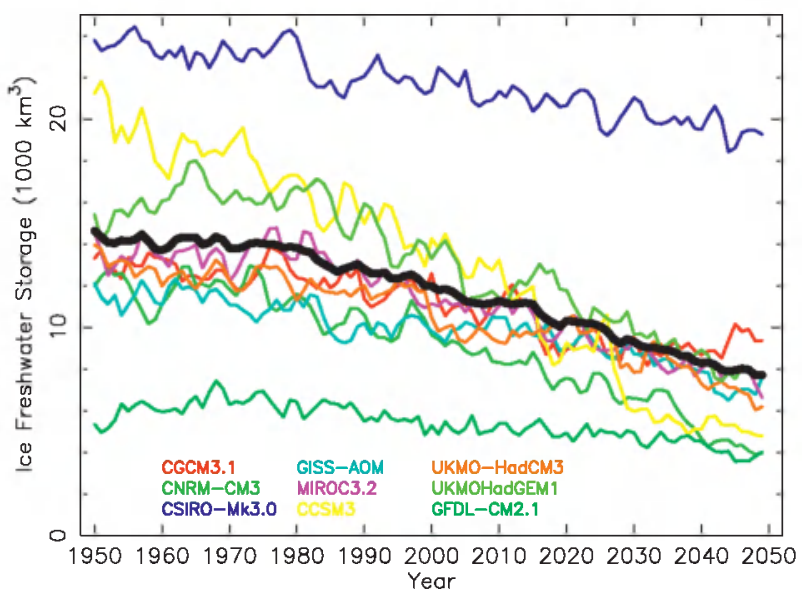

FIG. 8. Freshwater storage in sea ice, 1950-2049. The heavy black line is the multimodel mean.

models is nearly half that or a decline of only around $13 \%$. One potential caveat is that the submarine ice thickness data come only from the central basin, whereas the model includes seasonal areas that may have experienced a lesser decline.

It is likely that we will see a continuing decline of freshwater storage in the ice. The lengthening melt season will result in continued thinning of the ice and a steady decrease in ice extent. Further, the ice is prone to episodic wind events, such as the Arctic Oscillation shift around 1990 that flushed old, thick ice out of the Arctic Ocean. The thinning of the ice has led many to refer to the ice pack as "vulnerable" both to steady warming and episodic events.

\section{2) OCEAN}

Steele and Ermold (2004), Swift et al. (2005), Dmitrenko et al. (2008), and Polyakov et al. (2008) find that between the late 1960s-1970s and the late 1990s, freshwater declined in the central Arctic Ocean, whereas it increased (but to a much lesser extent) on the Russian arctic shelves to the west of the East Siberian Sea. The central Arctic decline was $\sim 1500 \mathrm{~km}^{3}$, composed of relatively long periods $(\sim 15 \mathrm{yr})$ of increasing values, alternating with shorter $(\sim 5 \mathrm{yr})$ periods of decline. This behavior was described as a "freshwater capacitor" by Proshutinsky et al. (2002), referring to the buildup of freshwater within the Beaufort Gyre and its subsequent release to the North Atlantic Ocean over a relatively shorter period. An example from the late 1980s to early 1990s was simulated in an ice-ocean model study by Karcher et al. (2005). This alternating increase-decrease in ocean freshwater has been linked to wind forcing associated with the Arctic Oscillation, although other factors may also play a role. In recent years (since 2000), this

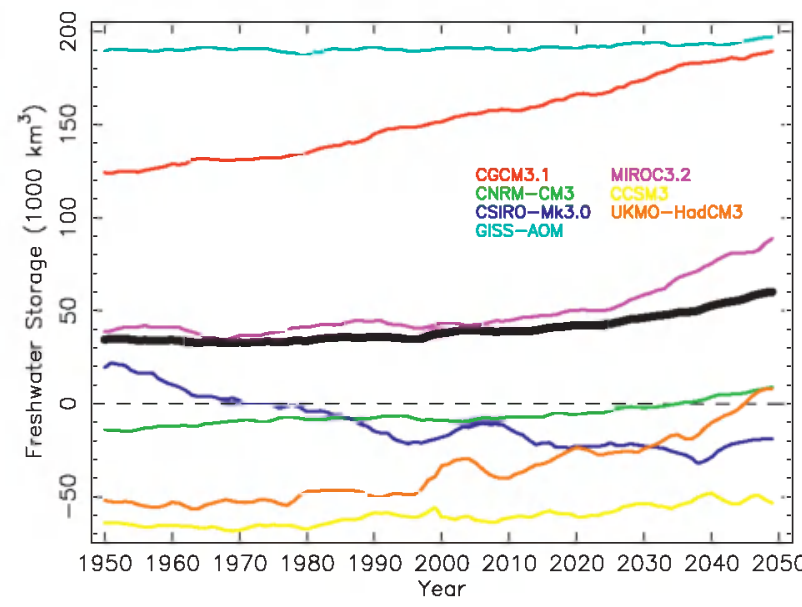

FIG. 9. Liquid freshwater storage, 1950-2049. The heavy black line is the multimodel mean.

index has declined, which suggests a collection of freshwater in the Beaufort Gyre as noted by McPhee et al. (2009).

Figure 9 extends the results of Holland et al. (2007) by showing detailed ocean freshwater time series from the available IPCC CMIP3 models. Over the latter half of the twentieth century, most models show a relatively weak freshwater increase, which for the multimodel mean amounts to about $3000 \mathrm{~km}^{3}$. This is of the opposite sign and double the value of the observed freshwater decrease over this time period. Why is this? The observed changes in freshwater storage respond to wind forcing associated with low-frequency variations in the Arctic Oscillation (Steele and Ermold 2007; Polyakov et al. 2008). These variations acted to collect freshwater (sea ice plus ocean freshwater) in the Arctic Ocean before the 1960s and then to force it southward into the North Atlantic Ocean through the rest of the century. It is likely that some component of this time evolution was the result of intrinsic climate variability, the observed phase that climate models are not expected to capture, even with ensemble runs. Climate models generally simulate much weaker trends in the Arctic Oscillation over the late twentieth century than observed (Gillett et al. 2002; Teng et al. 2006). However, it is unclear whether this discrepancy arises from a deficiency in the models' simulated response to anthropogenic forcing or the fact that some Arctic Oscillation anomalies represent extremely large variations in the real climate system.

\section{c. Summary of marine freshwater changes}

Table 6 summarizes the observed trends in sea ice and ocean freshwater fluxes and storage, as determined from the information in previous sections. We note no trend 
TABLE 6. Summary of ice and ocean FW changes in fluxes and storage, where positive indicates increasing FW within the Arctic Ocean. Where a linear regression of the trend has been performed, the slope with confidence interval is indicated.

\begin{tabular}{|c|c|c|}
\hline & Time period & Change $\left(\mathrm{km}^{3} \mathrm{yr}^{-2}\right)$ \\
\hline \multicolumn{3}{|l|}{ Sea ice FW fluxes: } \\
\hline Fram Strait (areal flux) ${ }^{\mathrm{a}}$ & $1979-2007$ & $0(95 \%)$ \\
\hline Fram Strait (volume flux) ${ }^{\mathrm{b}}$ & $1991-2008$ & 0 \\
\hline Barents Sea (areal flux) ${ }^{c}$ & $1979-2007$ & $0(95 \%)$ \\
\hline Bering Strait $^{\mathrm{d}}$ & - & - \\
\hline Canadian Archipelago ${ }^{e}$ & $1996-2002$ & \\
\hline \multicolumn{3}{|l|}{ Ocean FW fluxes: } \\
\hline Fram Strait $^{\mathrm{f}}$ & $1997-2007$ & 0 \\
\hline Barents Sea ${ }^{g}$ & $1965-2005$ & 2 \\
\hline Bering Strait ${ }^{\mathrm{h}}$ & $1990-2007$ & \\
\hline Canadian Archipelago & $2004-2007$ & - \\
\hline Net precipitation ${ }^{\mathrm{j}}$ & $1980-98$ & 0 \\
\hline Sea ice freshwater storage ${ }^{k}$ & $1980-2000$ & -248 \\
\hline Occan freshwater storage ${ }^{1}$ & $1970-2000$ & $-50(95 \%)$ \\
\hline \multicolumn{3}{|l|}{ a Kwok (2009). } \\
\hline \multirow{5}{*}{\multicolumn{3}{|c|}{$\begin{array}{l}\text { b Spreen et al. (2009) find no statistically significant change (at } \\
99 \% \text { confidence) of the mean over } 2003-08 \text {, relative to the mean } \\
\text { over 1991-99 as analyzed by Kwok et al. (2004). } \\
\text { " Measured at the northern boundary (Kwok 2009). } \\
\text { d No estimate of a trend has been provided in the literature. } \\
\text { e No trend estimate was attempted for these short time series, mea- } \\
\text { sured at Amundsen Gulf, M'Clure Strait, the Queen Elizabeth } \\
\text { Islands, and Nares Strait (Kwok et al. 2005; Kwok 2006). } \\
\text { fe Steur (2009) finds a "relatively constant" flux over this short } \\
\text { time series. }\end{array}$}} \\
\hline & & \\
\hline & & \\
\hline & & \\
\hline & & \\
\hline \multirow{2}{*}{\multicolumn{3}{|c|}{$\begin{array}{l}\text { Assuming a linear change of } 59 \mathrm{~km}^{3} \mathrm{yr}^{-1} \text { between } 1975 \text { and } 1995 \text {, } \\
\text { the midpoints of the two time periods provided in Table } 5 \text {. } \\
\text { h Woodgate et al. (2006) do not provide a trend over the entire time } \\
\text { series, although they do note a recent flux increase. }\end{array}$}} \\
\hline & & \\
\hline \multicolumn{3}{|c|}{$\begin{array}{l}\text { 'Mooring observations at Davis Strait (unpublished) indicate no } \\
\text { statistically significant trend over this very short time series. }\end{array}$} \\
\hline \multicolumn{3}{|c|}{$\begin{array}{l}\text { ' For the Arctic Ocean, excluding the Barents and Kara Seas, Groves } \\
\text { and Francis ( } 2002 \text { ) find no statistically significant change (at } 95 \% \\
\text { confidence) between the mean over 1989-98, relative to the mean } \\
\text { over } 1980-88 \text {. }\end{array}$} \\
\hline \multicolumn{3}{|c|}{$\begin{array}{l}{ }^{k} \text { Linearizing the } 67 \% \text { decline in ice draft over this period found by } \\
\text { Rothrock et al. (2008) with } 99 \% \text { confidence, starting with an ice } \\
\text { volume of } 15000 \mathrm{~km}^{3} \text { as provided by the multimodel ensemble } \\
\text { mean. }\end{array}$} \\
\hline \multicolumn{3}{|c|}{ ' Polyakov et al. (2008) and Steele and Ermold (2007). } \\
\hline
\end{tabular}

in the observed record of net sea ice FW flux, even though there is a decline in the sea ice storage. How can this be? If the observed sea ice storage decline is real, then one explanation is that the observed ice flux estimates are lacking, which is certainly possible. Another potential scenario is that ice volume export could, in the short term, remain constant as the thickness declines but the average speed increases. Such an increase in speed, associated with a decline in internal stresses, has been noted recently by Rampal et al. (2009). (However, note that such a speed increase should probably be evident in the area export, which has not been observed.)
The long-term net ocean FW flux trend is difficult to determine, given the short time series available from most straits. Observations indicate a decline in ocean freshwater storage over the last few decades of the twentieth century. Only the Barents Sea ocean flux observations cover that time period, and these indicate a gain of freshwater. It seems difficult to draw any firm conclusions about trends in the ocean FW budget at this time. However, this is likely to change in the near future, as ocean-observing programs started just before and during the International Polar Year begin to produce comprehensive time series of annual flux data at all straits.

\section{Summary and synthesis}

We have examined time series from observations and GCMs to understand whether the Arctic FWC is intensifying as expected because of warming. By computing trends from a suite of coupled climate models, we attempt to identify the regional climate "signal" while minimizing noise due to model parameterizations. The ensemble mean trend that emerges is the signal forced within the model simulations. Thus, trends derived using observed data-realizations subject to weather noise and sampling error - can be evaluated and compared to the predictive models to better understand how the Arctic system has responded, relative to expectations. This task is complicated by the relatively short period of record for many of the observations and the significant interannual variability inherent in the system.

Precipitation and ET have both increased over the past several decades. For the terrestrial Arctic, both GCMs and observations exhibit positive precipitation trends. Although observed precipitation trend magnitudes over more recent decades are greater than those over the 1950-99 interval, the robustness of the recent increases is limited. Small trends in these time series are largely obscured by natural variability. Consistency in significance across the GCM series is due to the effects of lower variability relative to the respective trend magnitude. A greater trend in the GCM multimodel mean for the period 1950-2049 versus 1950-99 suggests an accelerating response to warming. Changes in the frequency of extreme precipitation events, although difficult to assess because of the sparsity of observations, suggest intensification across areas north of $50^{\circ} \mathrm{N}$ latitude. The ET trends are all positive, with three of the four series exhibiting significant trends. They also (with one the exception) exceed the multimodel GCM trend. We speculate that upward ET trends are a manifestation of increasing precipitation together with a lengthened growing season. Model (LSMs and coupled GCMs) 
analysis of the factors controlling ET fluxes are needed to resolve differences in the trend magnitudes and linkage to other water cycle components.

Pan-Arctic river discharge, including discharge from ungauged regions, has also risen over recent decades. Among all components, the long-term increase in river discharge from large Eurasian rivers is perhaps the most consistent trend evidencing Arctic FWC intensification. The trend in the combined flow of the six largest Eurasian rivers over the period 1936-99 is approximately $7 \%$ (Peterson et al. 2002) and is consistent with models linking net precipitation increases to anthropogenic forcing (Wu et al. 2005). While discharge increases from Eurasia dominate the pan-Arctic trend, recent positive trends from Canada suggest that riverine intensification may now be pan-Arctic in extent. The time series of panArctic (including ungauged regions) annual discharge exhibits a trend that is nearly double the multimodel mean GCM $P-$ ET trend. What might explain why the trend in observed river discharge exceeds the trend in net precipitation simulated by the models? One potential explanation involves recent reported increases in winter precipitation, which we speculate may not be adequately captured by the GCMs. There is evidence that the discharge-precipitation ratio has increased across Eurasia over the latter decades of the twentieth century. In other words, more of the increasing precipitation flux may now become discharge each year. This change would be one way for the discharge increases to keep pace with precipitation increases. Changes in storage may also be involved. Drainage from water bodies (lakes and ponds) and thawing permafrost are two additional freshwater sources that could directly contribute to increases in river discharge and ET. These contributions would represent water cycle changes not directly linked with intensification as expressed through physics involving the Clausius-Clapeyron relation.

River discharge from Eurasia strongly influences freshwater budgets along the Russian shelves, which freshened in recent decades. Ocean circulation, however, plays a dominant role in this region and largely drives the freshwater balance (Steele and Ermold 2004). Regarding trends in Arctic Ocean fluxes and stocks, Arctic Oscillation trends created a freshwater buildup (ice and ocean) through the 1960 s and then a release of this freshwater through the rest of the century. This effect dominated the slow increase in freshwater inflows from rivers and other sources. What will happen in the future? It seems likely that wind forcing will continue to play an important role, sequestering and then releasing both ocean and ice freshwater over multiyear time scales. However, over the longer term, increasing freshwater inputs from river discharge, from ocean advection, and from net precipitation may eventually come to dominate the budget and lead to an increasing Arctic Ocean freshwater content, although this is uncertain.

Simulations with coupled GCMs suggest an intensification of the Arctic FWC in response to rising greenhouse gas concentrations. Observations also suggest intensification across the terrestrial system. That being said, our confidence in these change signals, with the exception of Eurasian river discharge, is somewhat limited. The lack of strongly significant trends in some of the observations is reflective of the considerable variability in Arctic freshwater system and the sparse/incomplete measures of precipitation, ET, and river discharge. Intensification of oceanic freshwater fluxes cannot be ascertained given the short records. Additional GCM runs have been made available to the community during the completion of this analysis, and new model runs are being currently produced as part of the IPCC Fifth Assessment Report. Direct observations of the Arctic FWC are continually being updated and made available as well. Future analysis to update the assessments presented here will be an important contribution to the emerging body of evidence documenting Arctic hydrologic change. Continued positive trends over coming years will need to occur to increase our confidence that the Arctic FWC is intensifying as expected because of climatic warming.

Acknowledgments. We acknowledge the modeling groups, the Program for Climate Model Diagnosis and Intercomparison (PCMDI) and the WCRP's Working Group on Coupled Modeling (WGCM) for their roles in making available the WCRP CMIP3 multimodel dataset. Support of this dataset is provided by the Office of Science, U.S. Department of Energy. We gratefully acknowledge funding from the National Science Foundation's Office of Polar Programs through the Freshwater Integration Project and from NASA's Cryosphere Program. Funding was provided through NSF Grants ARC-0531040, ARC-0531302, ARC-0612062, ARC0629471, ARC-0632154, ARC-0632231, ARC-0633885, ARC-0652838, ARC-0805789, OPP-0229705, OPP0230083, OPP-0230211, OPP-0230381, OPP-0328686, OPP-0335941, and OPP-0352754 and NASA Grants NNG06GE43G, NNH04AA66I, NNH08AI57I, and NNX08AN58G. The lead author was supported by fellowships from the NASA Postdoctoral Program and the New Hampshire Space Grant Consortium. Portions of this work were carried out at the Jet Propulsion Laboratory, California Institute of Technology, under contract with the National Aeronautics and Space Administration. Any use of trade, product, or firm names in this publication is for descriptive purposes only and does not imply endorsement by the U.S. Government. 


\section{REFERENCES}

Aagaard, K., and E. C. Carmack, 1989: The role of sea ice and other fresh waters in the Arctic circulation. J. Geophys. Res., 94, 14 485-14 498 .

Adam, J. C., I. Haddeland, F. Su, and D. P. Lettenmaier, 2007: Simulation of reservoir influences on annual and seasonal streamflow changes for the Lena, Yenisei, and $\mathrm{Ob}$ rivers. J. Geophys. Res., 112, D24114, doi:10.1029/2007JD008525.

Alexander, L. V., and Coauthors, 2006: Global observed changes in daily climate extremes of temperature and precipitation. J. Geophys. Res., 111, D05109, doi:10.1029/2005JD006290.

Allen, M. R., and W. J. Ingram, 2002: Constraints on future changes in climate and the hydrologic cycle. Nature, 419, 224-232.

Berbery, E. G., and V. R. Barros, 2002: The hydrologic cycle of the La Plata Basin in South America. J. Hydrometeor., 3, 630-645.

Berner, J., and Coauthors, Eds., 2005: Arctic Climate Impact Assessment. Cambridge University Press, 1042 pp.

Betts, A. K., J. H. Ball, and P. Viterbo, 2003: Evaluation of the ERA-40 surface water budget and surface temperature for the Mackenzie River basin. J. Hydrometeor., 4, 1194-1211.

Björk, G., B. G. Gustafsson, and A. Stigebrandt, 2001: Upper layer circulation in the Nordic Seas as inferred from the spatial distribution of heat and freshwater content and potential energy. Polar Res., 20, 161-168.

Bogdanova, E. G., B. M. Ilyin, and I. V. Dragomilova, 2002: Application of a comprehensive bias-correction model to precipitation measured at Russian North Pole drifting stations. J. Hydrometeor., 3, 700-713.

Bradley, R. S., H. F. Diaz, J. K. Eischeid, P. D. Jones, P. M. Kelly, and C. M. Goodess, 1987: Precipitation fluctuations over Northern Hemisphere land areas since the mid 19th century. Science, 237, 171-175.

Bromwich, D. H., and R. L. Fogt, 2004: Strong trends in the skill of the ERA-40 and NCEP-NCAR reanalyses in the high and middle latitudes of the Southern Hemisphere, 1958-2001. J. Climate, 17, 4603-4619.

Brown, J., K. M. Hinkel, and F. E. Nelson, 2000: The Circumpolar Active Layer Monitoring (CALM) program. Polar Geogr., 24, $165-258$.

Brown, R. D., and B. E. Goodison, 1996: Interannual variability in reconstructed Canadian snow cover, 1915-1992. J. Climate, 9, $1299-1318$.

Bulygina, O. N., V. N. Razuvaev, and N. N. Korshunova, 2009: Changes in snow cover over Northern Eurasia in the last few decades. Environ. Res. Lett., 4, 045026, doi:10.1088/1748-9326/ 4/4/045026.

Cherkauer, K. A., L. C. Bowling, and D. P. Lettenmaier, 2003: Variable infiltration capacity cold land process model updates. Global Planet. Change, 38, 151-159.

Climatic Research Unit, cited 2009: CRU TS3.0 dataset. [Available online at http://badc.nerc.ac.uk/data/cru/.]

Comiso, J. C., and F. Nishio, 2008: Trends in the sea ice cover using enhanced and compatible AMSR-E, SSM/I, and SMMR data. J. Geophys. Res., 113, C02S07, doi:10.1029/2007JC004257.

Cuny, J., P. B. Rhines, and R. Kwok, 2005: Davis Strait volume, freshwater and heat fluxes. Deep-Sea Res. I, 52, 519-542.

Curry, R., B. Dickson, and I. Yashayaev, 2003: A change in the freshwater balance of the Atlantic Ocean over the past four decades. Nature, 426, 826-829.

Dai, A., T. Qian, K. E. Trenberth, and J. D. Milliman, 2009: Changes in continental freshwater discharge from 1948 to 2004. J. Climate, 22, 2773-2791.
Déry, S. J., and R. D. Brown, 2007: Recent Northern Hemisphere snow cover extent trends and implications for the snowalbedo feedback. Geophys. Res. Lett., 34, L22504, doi:10.1029/ 2007GL031474.

—, J. Sheffield, and E. F. Wood, 2005: Connectivity between Eurasian snow cover extent and Canadian snow water equivalent and river discharge. J. Geophys. Res., 110, D23106, doi: $10.1029 / 2005 J D 006173$.

— - M. A. Hernández-Henríquez, J. E. Burford, and E. F. Wood, 2009: Observational evidence of an intensifying hydrological cycle in northern Canada. Geophys. Res. Lett., 36, L13402, doi:10.1029/2009GL038852.

de Steur, L., L. E. Hansen, R. Gerdes, M. Karcher, E. Fahrbach, and J. Holfort, 2009: Freshwater fluxes in the East Greenland Current: A decade of observations. Geophys. Res. Lett., 36, L23611, doi:10.1029/2009GL041278,

Dickson, B., I. Yashayaev, J. Meincke, B. Turrell, S. Dye, and J. Holfort, 2002: Rapid freshening of the deep North Atlantic Ocean over the past four decades. Nature, 416, 832-836.

Dickson, R., B. Rudels, S. Dye, M. Karcher, J. Meincke, and I. Yashayaev, 2007: Current estimates of freshwater flux through Arctic and subarctic seas. Prog. Oceanogr., 73, 210-230.

Dirmeyer, P. A., and K. L. Brubaker, 2007: Characterization of the global hydrologic cycle from a back-trajectory analysis of atmospheric water vapor. J. Hydrometeor., 8, 20-37.

Dmitrenko, I. A., S. A. Kirillov, L. B. Tremblay, D. Bauch, and M. Makhotin, 2008: The long-term and interannual variability of summer fresh water storage over the eastern Siberian shelf: Implication for climatic change. J. Geophys. Res., 113, C03007, doi: $10.1029 / 2007$ JC004304.

Dyurgerov, M., and M. Meier, 2000: Twentieth century climate change: Evidence from small glaciers. Proc. Natl. Acad. Sci. USA, 97, 1406-1411.

, and - 2005: Year-to-year fluctuations of global mass balance of small glaciers and their contribution to sea-level changes. Arct. Antarct. Alp. Res., 29, 392-402.

European Centre for Medium-Range Weather Forecasts, 2002: ERA-40 Project Report Series. 3. Workshop on Re-analysis, 5-9 November 2001. ECMWF Tech. Rep., 443 pp.

Fernandes, R., V. Korolevych, and S. Wang, 2007: Trends in land evapotranspiration over Canada for the period 1960-2000 based on in situ climate observations and a land surface model. J. Hydrometeor., 8, 1016-1030.

Finnis, J., J. J. Cassano, M. Holland, M. C. Serreze, and P. Uotila, 2009: Synoptically forced hydroclimatology of major Arctic watersheds in general circulation models. Part 2: Eurasian watersheds. Int. J. Climatol., 29, 1244-1261.

Førland, E. J., and I. Hanssen-Bauer, 2000: Increased precipitation in the Norwegian Arctic: True or false? Climatic Change, 46, $485-509$.

Francis, J. A., J. J. Cassano, W. J. Gutowski Jr., L. D. Hinzman, M. M. Holland, M. A. Steele, D. M. White, and C. J. Vörösmarty, 2009: An Arctic hydrologic system in transition: Feedbacks and impacts on terrestrial, marine, and human life. J. Geophys. Res., 114, G04019, doi:10.1029/2008JG000902.

Frauenfeld, O., T. Zhang, R. G. Barry, and D. G. Gilichinsky, 2004: Interdecadal changes in seasonal freeze and thaw depths in Russia. J. Geophys. Res., 109, D05101, doi:10.1029/ 2003JD004245.

Frey, K. E., and L. C. Smith, 2003: Recent temperature and precipitation increases in West Siberia and their association with the Arctic Oscillation. Polar Res., 22, 287-300. 
Frich, P., L. V. Alexander, P. Della-Marta, B. Gleason, M. Haylock, A. M. G. Klein-Tank, and T. C. Peterson, 2002: Observed coherent changes in climatic extremes during the second half of the twentieth century. Climate Res., 19, 193-212.

Gaffen, D. J., and R. J. Ross, 1998: Increased summertime heat stress in the US. Nature, 396, 529-530.

Giles, K. A., S. W. Laxon, and A. L. Ridout, 2008: Circumpolar thinning of Arctic sea ice following the 2007 record ice extent minimum. Geophys. Res. Lett., 35, L22502, doi:10.1029/ 2008GL035710

Gillett, N., M. Allen, R. McDonald, C. Senior, D. Shindell, and G. Schmidt, 2002: How linear is the Arctic Oscillation response to greenhouse gases? J. Geophys. Res., 107, 4022, doi:10.1029/2001JD000589.

Goodison, B. E., P. Y. T. Louie, and D. Yang, 1998: WMO solid precipitation measurement intercomparison. World Meteorological Organization Rep. WMO/TD 872,212 pp.

Gorodetskaya, I. V., L. B. Tremblay, B. Liepert, M. A. Cane, and R. I. Cullather, 2008: The influence of cloud and surface properties on the Arctic Ocean shortwave radiation budget in coupled models. J. Climate, 21, 866-882.

Groisman, P. Ya., V. V. Koknaeva, T. A. Belokrylova, and T. R. Karl, 1991: Overcoming biases of precipitation measurement: A history of the USSR experience. Bull. Amer. Meteor. Soc., 72, 1725-1733.

- and Coauthors, 2003: Contemporary climate changes in high latitudes of the Northern Hemisphere: Daily time resolution. Proc. 14th Symp. on Global Change and Climate Variations, Long Beach, CA, Amer. Meteor. Soc., 4.8. [Available online at http:/ams.confex.com/ams/annual2003/techprogram/paper_ 54814.htm.]

- R. W. Knight, D. R. Easterling, T. R. Karl, G. C. Hegerl, and V. N. Razuvaev, 2005: Trends in intense precipitation in the climate record. J. Climate, 18, 1326-1350.

, and Coauthors, 2007: Potential forest fire danger over Northern Eurasia: Changes during the 20th century. Global Planet. Change, 56, 371-386.

Groves, D. G., and J. A. Francis, 2002: Variability of the Arctic atmospheric moisture budget from TOVS satellite data. J. Geophys. Res., 107, 4785, doi:10.1029/2002JD002285.

Hanssen-Bauer, I., and E. J. Forland, 1994: Homogenizing of long Norweigian precipitation series. J. Climate, 7, 1001-1013.

Harris, C., and Coauthors, 2003: Warming permafrost in European mountains. Global Planet. Change, 39, 215-225.

Held, I. M., and B. J. Soden, 2006: Robust responses of the hydrological cycle to global warming. J. Climate, 19, 5686-5699.

Holfort, J., and E. Hansen, 2005: Timeseries of polar water properties in Fram Strait. Geophys. Res. Lett., 32, L19601, doi:10.1029/ 2005 GL022957.

- - , S. Østerhus, S. Dye, S. Jónsson, J. Meincke, J. Mortensen, and M. Meredith, 2008: Freshwater fluxes east of Greenland. Arctic-Subarctic Ocean Fluxes: Defining the Role of the Northern Seas in Climate, R. R. Dickson et al., Eds., Springer-Verlag, doi:10.1007/978-1-4020-6774-7.

Holland, M. M., J. Finnis, and M. C. Serreze, 2006: Simulated Arctic Ocean freshwater budgets in the twentieth and twentyfirst centuries. J. Climate, 19, 6221-6242.

- — A. P. Barrett, and M. C. Serreze, 2007: Projected changes in Arctic Ocean freshwater budgets. J. Geophys. Res., 112, G04S55, doi:10.1029/2006JG000354.

_ M. C. Serreze, and J. Stroeve, 2010: The sea ice mass budget of the Arctic and its future change as simulated by coupled climate models. Climate Dyn., 34, 185-200.
Huntington, T. G., 2004: Climate change, growing season length, and transpiration: Plant response could alter hydrologic regime. Plant Biol., 6, 651-653.

- 2006: Evidence for intensification of the global water cycle: Review and synthesis. J. Hydrol., 319, 83-95.

Ingvaldsen, R., H. Loeng, and L. Asplin, 2002: Variability in the Atlantic inflow to the Barents Sea based on a one-year time series from moored current meters. Cont. Shelf Res., 22, 505-519.

Kalnay, E., and Coauthors, 1996: The NCEP/NCAR 40-Year Reanalysis Project. Bull. Amer. Meteor. Soc., 77, 437-471.

Karcher, M., R. Gerdes, F. Kauker, C. Koberle, and I. Yashayaev, 2005: Arctic Ocean change heralds North Atlantic freshening. Geophys. Res. Lett., 32, L21606, doi:10.1029/2005GL023861.

Kattsov, V. M., J. E. Walsh, W. L. Chapman, V. A. Govorkova, T. V. Pavlova, and X. Zhang, 2007: Simulation and projection of Arctic freshwater budget components by the IPCC AR4 global climate models. I. Hydrometeor., 8, 571-589.

Keim, B. D., M. R. Fischer, and A. M. Wilson, 2005: Are there spurious precipitation trends in the United States Climate Division database? Geophys. Res. Lett., 32, L04702, doi:10.1029/ 2004 GL021985.

Keller, K., J. D. Blum, and G. W. Kling, 2010: Stream geochemistry as an indicator of increasing permafrost thaw depth in an arctic watershed. Chem. Geol., 273, 76-81.

Khon, V. C., I. I. Mokhov, E. Roeckner, and V. A. Semenov, 2007: Regional changes of precipitation characteristics in northern Eurasia from simulations with global climate model. Global Planet. Change, 57, 118-123.

Korzun, V. I., 1978: World water balance and water resources of the earth. Vol. 25, Studies and Reports in Hydrology, UNESCO, $663 \mathrm{pp}$.

Kwok, R., 2006: Exchange of sea ice between the Arctic Ocean and the Canadian Arctic Archipelago. Geophys. Res. Lett., 33, L16501, doi:10.1029/2006GL027094.

, 2009: Outflow of Arctic Ocean sea ice into the Greenland and Barents Seas: 1979-2007. J. Climate, 22, 2438-2457.

_- G. F. Cunningham, and S. S. Pang, 2004: Fram Strait sea ice outflow. J. Geophys. Res., 109, C01009, doi:10.1029/ 2003JC001785

,-- , and $—, 2005$ : Variability of Nares Strait ice flux. Geophys. Res. Lett., 32, L24502, doi:10.1029/2005GL024768.

Lambert, F. H., and M. J. Webb, 2008: Dependency of global mean precipitation on surface temperature. Geophys. Res. Lett., 35, L16706, doi:10.1029/2008GL034838.

Lammers, R. B., A. I. Shiklomanov, C. J. Vörösmarty, B. M. Fekete, and B. J. Peterson, 2001: Assessment of contemporary Arctic river runoff based on observational discharge records. J. Geophys. Res., 106, 3321-3334.

Lawrence, D. M., and A. G. Slater, 2005: A projection of severe near-surface permafrost degradation during the 21st century. Geophys. Res. Lett., 32, L24401, doi:10.1029/2005GL025080.

Lewis, E. L., Ed., 2000: The Freshwater Budget of the Arctic Ocean . Kluwer Academic, 644 pp.

Liang, X., D. P. Lettenmaier, E. F. Wood, and S. J. Burges, 1994: A simple hydrologically based model of land surface water and energy fluxes for general circulation models. J. Geophys. Res., 99, 14 415-14 428

McClelland, J. W., R. M. Holmes, B. J. Peterson, and M. Stieglitz, 2004: Increasing river discharge in the Eurasian Arctic: Consideration of dams, permafrost thaw, and fires as potential agents of change. J. Geophys. Res., 109, D18102, doi:10.1029/ 2004JD004583. 
— , S. J. Déry, B. J. Peterson, R. M. Holmes, and E. F. Wood, 2006: A pan-arctic evaluation of changes in river discharge during the latter half of the 20th century. Geophys. Res. Lett., 33, L06715, doi:10.1029/2006GL025753.

McDonald, K. C., J. S. Kimball, E. Njoku, R. Zimmermann, and M. Zhao, 2004: Variability in springtime thaw in the terrestrial high latitudes: Monitoring a major control on biospheric assimilation of atmospheric $\mathrm{CO}_{2}$ with spaceborne microwave remote sensing. Earth Interactions, 8. [Available online at http://EarthInteractions.org.]

McPhee, M. G., A. Proshutinsky, J. H. Morison, M. Steele, and M. B. Alkire, 2009: Rapid change in freshwater content of the Arctic Ocean. Geophys. Res. Lett., 36, L10602, doi:10.1029/ 2009GL037525.

Menzel, A., and P. Fabian, 1999: Growing season extended in Europe. Nature, 397, 659.

Mitchell, T. D., T. R. Carter, P. D. Jones, M. Hulme, and M. New, cited 2004: A comprehensive set of high-resolution grids of monthly climate for Europe and the globe: The observed record (19012000) and 16 scenarios (2001-2100). [Available online at http:// www.ipcc-data.org/docs/tyndall_working_papers_wp55.pdf.]

Mu, Q., F. A. Heinsch, M. Zhao, and S. W. Running, 2007: Development of a global evapotranspiration algorithm based on MODIS and global meteorology data. Remote Sens. Environ., 111, 519-536.

Munchow, A., H. Melling, and K. K. Falkner, 2006: An observational estimate of volume and freshwater flux leaving the Arctic Ocean through Nares Strait. J. Phys. Oceanogr., 36, 2025-2041.

National Climatic Data Center, cited 2005: Daily and sub-daily precipitation for the former USSR. [Available online at http:// www1.ncdc.noaa.gov/pub/data/documentlibrary/tddoc/td9813. pdf.]

Oberman, N. G., and G. G. Mazhitowa, 2001: Permafrost dynamics in the northeast of European Russia at the end of the 20th century. Norwegian J. Geogr., 55, 241-244.

O'Gorman, P. A., and T. Schneider, 2009: Scaling of precipitation extremes over a wide range of climates simulated with an idealized GCM. J. Climate, 22, 5676-5685.

Orvik, K. A., O. Skagseth, and M. Mork, 2001: Atlantic inflow to the Nordic Seas: Current structure and volume fluxes from moored current meters, VM-ADCP, and SeaSoar-CTD observations, 1995-1999. Deep-Sea Res. I, 48, 937-957.

Osterkamp, T. E., 2005: The recent warming of permafrost in Alaska. Global Planet. Change, 49, 187-202.

Östlund, H. G., and G. Hut, 1984: Arctic Ocean water mass balance from isotope data. J. Geophys. Res., 89, 6373-6381.

Park, H., T. Yamazaki, K. Yamamoto, and T. Ohta, 2008: Tempospatial characteristics of energy budget and evapotranspiration in the eastern Siberia. Agric. For. Meteor., 148, 1990-2005.

Pavlov, A. V., 1994: Current changes of climate and permafrost in the arctic and sub-arctic of Russia. Permafrost Periglacial Processes, 5, 101-110.

Peterson, B. J., R. M. Holmes, J. W. McClelland, C. J. Vörösmarty, R. B. Lammers, A. I. Shiklomanov, I. A. Shiklomanov, and S. Rahmstorf, 2002: Increasing river discharge to the Arctic Ocean. Science, 298, 2171-2173.

_ J. McClelland, R. Curry, R. M. Holmes, J. E. Walsh, and K. Aagaard, 2006: Trajectory shifts in the Arctic and subArctic freshwater cycle. Science, 313, 1061-1066.

Polyakov, I. V., and Coauthors, 2008: Arctic Ocean freshwater changes over the past 100 years and their causes. J. Climate, $\mathbf{2 1}$, 364-384.
Prinsenberg, S. J., and J. Hamilton, 2005: Monitoring the volume, freshwater and heat fluxes passing through Lancaster Sound in the Canadian Arctic Archipelago. Atmos.-Ocean, 43, 1-22.

Proshutinsky, A., R. H. Bourke, and F. A. McLaughlin, 2002: The role of the Beaufort Gyre in arctic climate variability: Seasonal to decadal climate scales. Geophys. Res. Lett., 29, 2100 , doi:10.1029/2002GL015847.

Prowse, T. D., and C. S. L. Ommaney, Eds., 1990: Northern hydrology: Canadian perspectives. National Hydrology Research Institute Science Rep. 1, 308 pp.

Rampal, P., J. Weiss, and D. Marsan, 2009: Positive trend in the mean speed and deformation rate of Arctic sea ice, 1979-2007. J. Geophys. Res., 114, C05013, doi:10.1029/2008JC005066.

Rawlins, M. A., C. J. Willmott, A. Shiklomanov, E. Linder, S. Frolking, R. B. Lammers, and C. J. Vörösmarty, 2006: Evaluation of trends in derived snowfall and rainfall across Eurasia and linkages with discharge to the Arctic Ocean. Geophys. Res. Lett., 33, L07403, doi:10.1029/2005GL025231.

— - and Coauthors, 2009a: Tracing freshwater anomalies through the air-land-ocean system: A case study from the Mackenzie River basin and the Beaufort Gyre. Atmos.-Ocean, 47, 79-97.

- H. Ye, D. Yang, A. Shiklomanov, and K. C. McDonald, 2009b: Divergence in seasonal hydrology across northern Eurasia: Emerging trends and water cycle linkages. J. Geophys. Res., 114, D18119, doi:10.1029/2009JD011747.

Robinson, D. A., and A. Frei, 2000: Seasonal variability of northern hemisphere snow extent using visible satellite data. Prof. Geogr., 52, 307-315.

Rothrock, D. A., D. B. Percival, and M. Wensnahan, 2008: The decline in arctic sea-ice thickness: Separating the spatial, annual, and interannual variability in a quarter century of submarine data. J. Geophys. Res., 113, C05003, doi:10.1029/ 2007JC004252.

Rudels, B., M. Marnela, and P. Eriksson, 2008: Constraints on estimating mass, heat and freshwater transports in the Arctic Ocean: An exercise. Arctic-Subarctic Ocean Fluxes: Defining the Role of the Northern Seas in Climate, R. R. Dickson et al., Eds., Springer, 315-341.

Santer, B. D., and Coauthors, 2007: Identification of human-induced changes in atmospheric moisture content. Proc. Natl. Acad. Sci. USA, 104, 15 248-15 253

Schiermeier, Q., 2006: Arctic stations need human touch. Nature, 441, 133 .

Schwartz, M. D., R. Ahas, and A. Ahas, 2006: Onset of spring starting earlier across the Northern Hemisphere. Global Change Biol., 12, 343-351.

Serreze, M. C., and Coauthors, 2000: Observational evidence of recent change in the northern high-latitude environment. Climatic Change, 46, 159-207.

- M. P. Clark, D. H. Bromwich, A. J. Etringer, T. Zhang, and R. Lammers, 2002: Large-scale hydroclimatology of the terrestrial Arctic drainage system. J. Geophys. Res., 107, 8160, doi:10.1029/2001JD000919.

, and Coauthors, 2006: The large-scale freshwater cycle of the Arctic. J. Geophys. Res., 111, C11010, doi:10.1029/2005JC003424.

Sheffield, J., and E. F. Wood, 2007: Characteristics of global and regional drought, 1950-2000: Analysis of soil moisture data from off-line simulation of the terrestrial hydrologic cycle. J. Geophys. Res., 112, D17115, doi:10.1029/2006JD008288.

, G. Goteti, and E. F. Wood, 2006: Development of a 50-year high-resolution global dataset of meteorological forcings for land surface modeling. J. Climate, 19, 3088-3111. 
Shiklomanov, A. I., and R. B. Lammers, 2009: Record Russian river discharge in 2007 and the limits to analysis. Environ. Res. Lett., 4, 045015, doi:10.1088/1748-9326/4/4/045015.

- $\longrightarrow$, and C. J. Vörösmarty, 2002: Widespread decline in hydrological monitoring threatens Pan-Arctic research. Eos, Trans. Amer. Geophys. Union, 83, 13-17.

, T. I. Yakovleva, R. B. Lammers, I. P. Karasev, C. J. Vörösmarty, and $\mathrm{E}$. Linder, 2006: Cold region river discharge uncertainty-Estimates from large Russian rivers. J. Hydrol., 326, 231-256.

Shiklomanov, I. A., A. I. Shiklomanov, R. B. Lammers, B. J. Peterson, and C. J. Vörösmarty, 2000: The dynamics of river water inflow to the Arctic Ocean. The Freshwater Budget of the Arctic Ocean, E. L. Lewis, et al., Eds., Kluwer Academic Press, 281-296.

Skagseth, Ø., T. Furevik, R. Ingvaldsen, H. Loeng, K. A. Mork, K. A. Orvik, and V. Ozhigin, 2008: Volume and heat transports to the Arctic via the Norwegian and Barents Seas. Arctic-Subarctic Ocean Fluxes: Defining the Role of the Northern Seas in Climate, R. R. Dickson et al., Eds., Springer Verlag, 45-64.

Slater, A. G., T. J. Bohn, J. L. McCreight, M. C. Serreze, and D. P. Lettenmaier, 2007: A multi-model simulation of panArctic hydrology. J. Geophys. Res., 112, G04S45, doi:10.1029/ 2006JG000303.

Smith, L. C., Y. Sheng, G. M. MacDonald, and L. D. Hinzman, 2005a: Disappearing arctic lakes. Science, 308, 1429.

Smith, S. L., M. M. Burgess, D. Riseborough, and F. M. Nixon, 2005b: Recent trends from Canadian permafrost thermal monitoring network sites. Permafrost Periglacial Processes, 16, 19-30.

Soja, A. J., and Coauthors, 2007: Climate-induced boreal forest change: Predictions versus current observations. Global Planet. Change, 56, 274-296.

Solomon, S., D. Qin, M. Manning, M. Marquis, K. Averyt, M. M. B. Tignor, H. L. Miller Jr., and Z. Chen, Eds., 2007: Climate Change 2007: The Physical Science Basis. Cambridge University Press, 996 pp.

Spreen, G., S. Kern, D. Stammer, and E. Hansen, 2009: Fram Strait sea ice volume export estimated between 2003 and 2008 from satellite data. Geophys. Res. Lett., 36, L19502, doi:10.1029/ 2009GL039591.

Steele, M., and W. Ermold, 2004: Salinity trends on the Siberian shelves. Geophys. Res. Lett., 31, L24308, doi:10.1029/2004GL021302.

— , and _ 2007: Steric sea level change in the Northern Seas. J. Climate, 20, 403-417.

Stroeve, J., M. M. Holland, W. Meier, T. Scambos, and M. C. Serreze, 2007: Arctic sea ice decline: Faster than forecast. Geophys. Res. Lett., 34, L09501, doi:10.1029/2007GL029703.

Swift, J. H., K. Aagaard, L. Timokhov, and E. G. Nikiforov, 2005: Long-term variability of arctic ocean waters: Evidence from a reanalysis of the EWG data set. J. Geophys. Res., 110, C03012, doi:10.1029/2004JC002312.

Tang, C. C. L., C. K. Ross, T. Yao, B. Petrie, B. M. DeTracey, and E. Dunlap, 2004: The circulation, water masses and sea-ice of Baffin Bay. Prog. Oceanogr., 63, 183-228.

Tebaldi, C., K. Hayhoe, J. M. Arblaster, and G. A. Meehl, 2006: Going to the extremes: An intercomparison of model-simulated historical and future changes in extreme events. Climatic Change, 79, 185-211

Teng, H., W. Washington, G. Meehl, L. Buja, and G. Strand, 2006: Twenty-first century Arctic climate change in the CCSM3 IPCC scenario simulations. Climate Dyn., 26, 601-616.
Trenberth, K. E., and A. Dai, 2007: Effects of Mount Pinatubo volcanic eruption on the hydrological cycle as an analog of geoengineering. Geophys. Res. Lett, 34, L15720, doi:10.1029/ 2007 GL030524.

Walter, M. T., D. S. Wilks, J.-Y. Parlange, and R. L. Schneider, 2004: Increasing evapotranspiration from the conterminous United States. J. Hydrometeor, 5, 405-408.

Wang, S., Y. Yang, A. P. Trishchenko, A. Barr, T. A. Black, and H. McCaughey, 2009: Modeling the response of canopy stomatal conductance to humidity. J. Climate, 10, 521-532.

Wentz, F. J., L. Ricciardulli, K. Hilburn, and C. Mears, 2007 How much more rain will global warming bring? Science, 317, 233-235.

White, D., and Coauthors, 2007: The Arctic freshwater system: Changes and impacts. J. Geophys. Res., 112, G04S54, doi:10.1029/ 2006JG000353

Willett, K. M., P. D. Jones, N. P. Gillett, and P. W. Thorne, 2008: Recent changes in surface humidity: Development of the HadCRUH dataset. J. Climate, 21, 5364-5383.

Willmott, C. J., and K. Matsuura, cited 2009: Terrestrial precipitation: 1900-2008 gridded monthly time series, version 2.01. [Available online at http://climate.geog.udel.edu/ climate/html_pages/ Global2_Ts_2009/README.global_p_ts_2009.html.]

Woodgate, R. A., and K. Aagaard, 2005: Revising the Bering Strait freshwater flux into the Arctic Ocean. Geophys. Res. Lett., 32, L02602, doi:10.1029/2004GL021747.

,-- , and T. J. Weingartner, 2006: Interannual changes in the Bering Strait fluxes of volume, heat and freshwater between 1991 and 2004. Geophys. Res. Lett., 33, L15609, doi:10.1029/ 2006 GL026931.

Wu, P., R. Wood, and P. Stott, 2005: Human influence on increasing Arctic river discharges. Geophys. Res. Lett., 32, L02703, doi:10.1029/2004GL021570.

Yang, D., D. L. Kane, L. D. Hinzman, X. Zhang, T. Zhang, and H. Ye, 2002: Siberian Lena River hydrologic regime and recent change. J. Geophys. Res., 107, 4694, doi:10.1029/2002JD002542. , B. Ye, and D. L. Kane, 2004a: Streamflow changes over Siberian Yenisei River Basin. J. Hydrol., 296, 59-80.

$[$, - and A. Shiklomanov, 2004b: Discharge characteristics and changes over the $\mathrm{Ob}$ river watershed in Siberia. $J$. $H y$ drometeor., 5, 595-610.

- D. Kane, Z. Zhang, D. Legates, and B. Goodison, 2005: Bias corrections of long-term (1973-2004) daily precipitation data over the northern regions. Geophys. Res. Lett., 32, L19501, doi:10.1029/2005GL024057.

Ye, B., D. Yang, and D. Kane, 2003: Changes in Lena River streamflow hydrology: Human impacts versus natural variations. Water Resour. Res., 39, 1200, doi:10.1029/2003WR001991.

__, _—, Z. Zhang, and D. Kane, 2009: Variation of hydrological regime with permafrost coverage over Lena Basin in Siberia. J. Geophys. Res., 114, D07102, doi:10.1029/2008JD010537.

Ye, H., H. R. Cho, and P. E. Gustafson, 1998: The changes in Russian winter snow accumulation during 1936-1983 and its spatial patterns. J. Climate, 11, 856-863.

Zhang, K., J. S. Kimball, E. H. Hogg, M. Zhao, w. C. Oechel, J. J. Cassano, and S. W. Running, 2008: Satellite-based model detection of recent climate-driven changes in northern highlatitude vegetation productivity. J. Geophys. Res., 113, G03033, doi:10.1029/2007JG000621.

-, Q. Mu, L. A. Jones, S. J. Goetz, and S. W. Running 2009: Satellite based analysis of northern ET trends and associated changes in the regional water balance from 1983 to 2005. J. Hydrol., 379, 92-110. 
Zhang, T., 2005: Influence of the seasonal snow cover on the ground thermal regime: An overview. Rev. Geophys., 43, RG4002, doi:10.1029/2004RG000157.

- , and T. E. Osterkamp, 1993: Changing climate and permafrost temperatures in the Alaskan Arctic. Proc. Sixth Int. Conf. on Permafrost, Beijing, China, South China University of Technology Press, 783-788.

, and Coauthors, 2005: Spatial and temporal variability in active layer thickness over the Russian Arctic drainage basin. J. Geophys. Res., 110, D16101, doi:10.1029/ 2004JD005642.

Zhang, X., L. A. Vincent, W. D. Hogg, and A. Niitsoo, 2000: Temperature and precipitation trends in Canada during the 20th century. Atmos.-Ocean, 38, 395-429.

Zhao, L., C. Ping, D. Yang, G. Cheng, Y. Ding, and S. Liu, 2004: Changes of climate and seasonally frozen ground over the past 30 years in Qinghai-Xizang (Tibetan) Plateau. Global Planet. Change, 43, 19-31. 